Article

\title{
Cytokinin Plant Hormones Have Neuroprotective Activity in In Vitro Models of Parkinson's Disease
}

\author{
Gabriel Gonzalez ${ }^{1,2}{ }^{\mathbb{D}}$, Jiří Grúz ${ }^{1}$, Cosimo Walter D'Acunto ${ }^{1}$, Petr Kaňovský ${ }^{2}$ and Miroslav Strnad ${ }^{1,2, *}$ \\ 1 Laboratory of Growth Regulators, Institute of Experimental Botany of the Czech Academy of Sciences, \\ and Faculty of Science, Palacký University, Šlechtitelů 27, CZ-78371 Olomouc, Czech Republic; \\ Gonzalez.gabriel@seznam.cz (G.G.); jiri.gruz@upol.cz (J.G.); waldacun@gmail.com (C.W.D.) \\ 2 Department of Neurology, University Hospital Olomouc and Faculty of Medicine and Dentistry, \\ Palacký University Olomouc, CZ-775 20 Olomouc, Czech Republic; Petr.Kanovsky@fnol.cz \\ * Correspondence: miroslav.strnad@upol.cz; Tel.: +420-585-634-850
}

Citation: Gonzalez, G.; Grúz, J.; D'Acunto, C.W.; Kaňovský, P.; Strnad, M. Cytokinin Plant Hormones Have Neuroprotective Activity in In Vitro Models of Parkinson's Disease. Molecules 2021, 26, 361. https:// doi.org/10.3390/molecules 26020361

Academic Editor: Luciana Mosca Received: 2 December 2020 Accepted: 10 January 2021 Published: 12 January 2021

Publisher's Note: MDPI stays neutral with regard to jurisdictional clai$\mathrm{ms}$ in published maps and institutional affiliations.

Copyright: $\odot 2021$ by the authors. Licensee MDPI, Basel, Switzerland. This article is an open access article distributed under the terms and conditions of the Creative Commons Attribution (CC BY) license (https:// creativecommons.org/licenses/by/ $4.0 /)$.
Abstract: Cytokinins are adenine-based phytohormones that regulate key processes in plants, such as cell division and differentiation, root and shoot growth, apical dominance, branching, and seed germination. In preliminary studies, they have also shown protective activities against human neurodegenerative diseases. To extend knowledge of the protection (protective activity) they offer, we investigated activities of natural cytokinins against salsolinol (SAL)-induced toxicity (a Parkinson's disease model) and glutamate (Glu)-induced death of neuron-like dopaminergic SH-SY5Y cells. We found that kinetin-3-glucoside, cis-zeatin riboside, and $\mathrm{N}^{6}$-isopentenyladenosine were active in the SAL-induced PD model. In addition, trans-, cis-zeatin, and kinetin along with the iron chelator deferoxamine (DFO) and the necroptosis inhibitor necrostatin 1 (NEC-1) significantly reduced cell death rates in the Glu-induced model. Lactate dehydrogenase assays revealed that the cytokinins provided lower neuroprotective activity than DFO and NEC-1. Moreover, they reduced apoptotic caspase-3/7 activities less strongly than DFO. However, the cytokinins had very similar effects to DFO and NEC-1 on superoxide radical production. Overall, they showed protective activity in the SAL-induced model of parkinsonian neuronal cell death and Glu-induced model of oxidative damage mainly by reduction of oxidative stress.

Keywords: cytokinin; phytohormone; neuroprotection; neuron-like SH-SY5Y cells; cytotoxicity; salsolinol; glutamate; oxidative stress; Parkinson's disease

\section{Introduction}

Parkinson's disease (PD) is the second most common motor-related neurodegenerative disease, and numbers of globally diagnosed cases are expected to rise from 6 million in 2015 to more than 12 million by 2040 [1]. It is characterized by motor symptoms linked with specific degeneration and loss of approximately $30-70 \%$ of dopaminergic (DA) neurons in the substantia nigra pars compacta and their projections to the striatum [2,3]. Some, of many, known molecular hallmarks of PD include enhanced oxidative and nitrosative stress, mitochondrial dysfunction [4-7], excitotoxicity [8], ubiquitin/proteasomal system dysfunction [9], and neuroinflammation [10]. Current treatments have various adverse side-effects and only offer symptomatic relief [11], so there are intense efforts to develop drugs with efficient curative effects on degenerating DA neurons. Resources that may aid such efforts include natural compounds that tend to have fewer side effects. Inter alia, substances from Ginkgo biloba (ginkgetin, ginkgolide, bilobalide), ginseng (ginsenosides), and flavonoids (baicalein, kaempferol, rutin and luteolin) have demonstrated broad protective activity in several in vitro models (including the human neuroblastoma cell line SH-SY5Y) and in vivo models of PD induced by 1,1'-dimethyl-4,4'-bipyridinium dichloride (paraquat), 1-methyl4-phenyl-1,2,3,6-tetrahydropyridine (MPTP), 1-methyl-4-phenylpyridinium (MPP+), and 6-hydroxydopamine (6-OHDA) [12]. 
The study presented here focused on effects of a class of natural phytohormones called cytokinins (CKs), and their metabolites, which are well known regulators of cell division, growth, differentiation, and leaf senescence in plants [13]. Structurally, CKs are adenine derivatives substituted at the $\mathrm{N}^{6}$-position with either a prenyl (isopentenyl) or aromatic sidechain. Natural forms include 6-(E)-4-hydroxy-3-methylbut-2-enylaminopurine (transzeatin, $t \mathbf{Z}$ ), its 6-(Z)-isomer (cis-zeatin, $c \mathbf{Z}$ ), $\mathrm{N}^{6}$-isopentenyladenine (iP), 6-benzylaminopurine (BAP), 6-furfurylaminopurine (kinetin, K), and ortho-, meta-, and para-hydroxylated or methoxylated derivatives of BAP, called topolins $(o \mathrm{~T}, m \mathrm{~T}, p \mathrm{~T}, \mathrm{Me} o \mathrm{~T}, \mathrm{Me} m \mathrm{~T}, \mathrm{Me} p \mathrm{~T})$. Various 9-ribosides, 9-nucleotides, as well as 7-, 9, and O-glucosides of these forms also commonly occur, as shown in Table 1. In addition to their native roles in plants, CKs have shown potent ant-oxidant activity towards reactive oxygen species (ROS) that provides protection in several in vitro stress models of aging-associated disorders [14].

Table 1. Structures of cytokinins and the positive control agents.

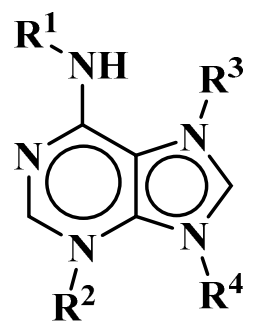

\begin{tabular}{|c|c|c|c|c|c|}
\hline $\mathbf{R}^{1}$ & $\mathbf{R}^{2}$ & $\mathbf{R}^{3}$ & $\mathbf{R}^{4}$ & Trivial Name & Abbreviation \\
\hline & - & - & $\mathrm{H}$ & $\mathrm{N}^{6}$-isopentenyladenine & iP \\
\hline & - & - & ribosyl & $\mathrm{N}^{6}$-isopentenyladenosine & $\mathrm{iPR}$ \\
\hline \multirow{5}{*}{${ }^{\mathrm{HO}}$} & - & - & $\mathrm{H}$ & trans-zeatin & $t Z$ \\
\hline & - & - & ribosyl & $t$-zeatin riboside & $t \mathrm{ZR}$ \\
\hline & - & glycosyl & - & t-zeatin-7-glucoside & $t Z 7 G$ \\
\hline & - & - & glycosyl & $t$-zeatin-9-glucoside & $t Z 9 G$ \\
\hline & - & - & ribonucleotide & tZR-5'-monophosphate & $t \mathrm{ZMP}$ \\
\hline
\end{tabular}

\begin{tabular}{|c|c|c|c|c|c|}
\hline Gluc & - & - & - & t-zeatin-O-glucoside & $t Z O G$ \\
\hline $\mathbf{H}$ & - & - & $\begin{array}{l}\mathrm{H} \\
\text { ribosyl }\end{array}$ & $\begin{array}{c}\text { cis-zeatin } \\
\text { c-zeatin riboside }\end{array}$ & $\begin{array}{l}c Z \\
c Z R\end{array}$ \\
\hline & - & - & $\begin{array}{c}\text { glycosyl } \\
\text { ribonucleotide }\end{array}$ & $\begin{array}{l}\text { c-zeatin-9-glucoside } \\
\text { cZR-5'-monophosphate }\end{array}$ & $\begin{array}{l}\text { cZ9G } \\
\text { cZMP }\end{array}$ \\
\hline & - & - & - & c-zeatin-O-glucoside & cZOG \\
\hline & - & - & $\mathrm{H}$ & 6-benzylaminopurine & BAP \\
\hline & - & - & $\mathrm{H}$ & meta-topolin & $m \mathrm{~T}$ \\
\hline OH & - & - & ribosyl & meta-topolin riboside & $m \mathrm{TR}$ \\
\hline
\end{tabular}


Table 1. Cont.

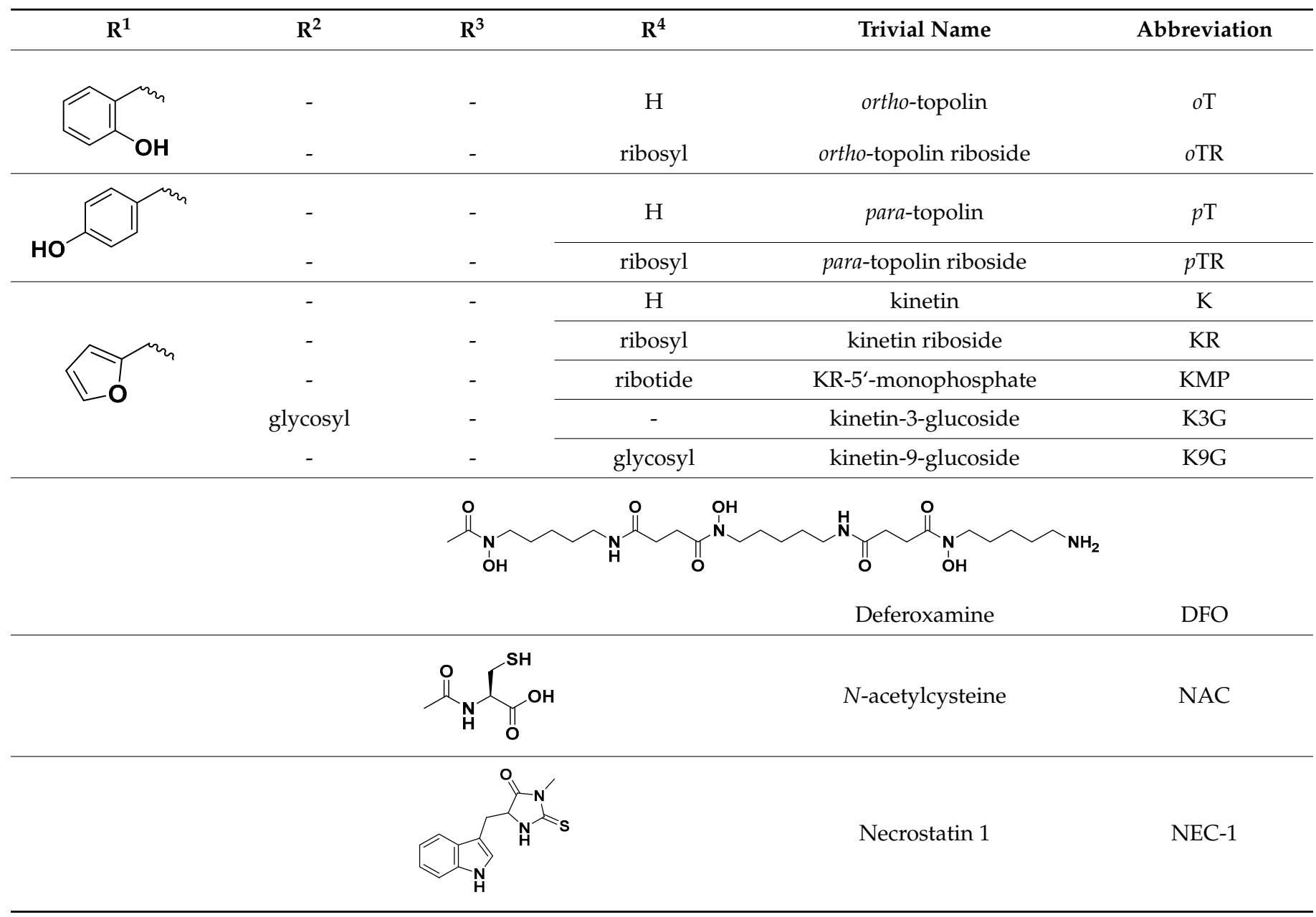

In particular, CKs reportedly have cytoprotective activity in models such as $\mathrm{H}_{2} \mathrm{O}_{2}$ induced cell death of human fibroblasts [15] and D-galactose-induced glycoxidative stress in rat astrocytes [16]. More importantly, in this context, they have shown neuroprotective effects in models related to neurodegenerative diseases such as familial PD, proteasome inhibitor MG 132-induced or $\mathrm{H}_{2} \mathrm{O}_{2}$-induced toxicity in SH-SY5Y cells [17], Glu-induced oxidative damage of HT22 mouse hippocampal neuronal cells [18], and the PC12 cell model of Huntington's disease [19]. Other studies indicate that CKs' protective activities involve both direct $[20,21]$ and indirect $[15,16,22]$ modulation of cellular redox systems. In addition to $\mathrm{CKs}^{\prime}$ characteristic antioxidant activities, they reportedly have regulatory effects in mitochondria that enhance neuronal viability [17]. Moreover, $\mathbf{K}$ can stabilize mitochondrial membrane potential and increase ATP production, thereby mitigating Glu-induced death of HT22 cells [18]. However, despite findings regarding their effects in several models, there is limited knowledge of $\mathrm{CKs}^{\prime}$ protective activity in the most common (sporadic) form of PD.

To address the knowledge gap described above, we systematically evaluated effects of natural CKs and their metabolites in two in vitro models: A salsolinol (SAL)-induced model of PD and glutamate (Glu)-induced model of oxidative damage in neuron-like SH-SY5Y cells. This line was used because of its dopaminergic phenotype, sensitivity to dopaminergic toxins such as SAL, and convenient formation of relatively stable populations of differentiated neuronal cells with reduced proliferation rates following $48 \mathrm{~h}$ exposure to $10 \mu \mathrm{M}$ all-trans retinoic acid (ATRA) [23-25].

Neuron-like cells were exposed to the endo/exotoxin SAL to mimic PD pathology via dysfunction of cellular redox system: Depletion of the glutathione (GSH), and inhibition 
of both anti-oxidant enzyme $(\mathrm{Cu} / \mathrm{Zn}$ superoxide dismutase and catalase) activities and mitochondrial complexes (I and II), leading to apoptosis and necrosis [26]. In the other model, Glu induces potentially lethal oxidative damage by disruption of the redox system. Both models in the SH-SY5Y cell line have been previously used in neuroprotection studies [26,27].

Cytoprotective and/or antioxidant activities related to degenerative disorders of $\mathbf{K}$, iP, BAP, iPR, $t$ ZR, and their free bases have been tested, and (as outlined above) some CKs have been found to have protective activities in neuronal cells. However, no previously published studies have examined the structure-neuroprotective activity relationship (SAR) of natural CKs (Table 1). Therefore, this study was undertaken to examine neuroprotective (anti-parkinsonian) activities of almost all known naturally occurring CKs in the selected SAL- and Glu-induced models of neurodegeneration. First, we evaluated each of the $\mathrm{CKs}^{\prime}$ oxygen radical absorbance capacity (ORAC) and (in safety tests) cytotoxicity towards neuron-like SH-SY5Y cells. Then, we evaluated the compounds' neuroprotective effects and influence on oxidative stress levels by measuring superoxide $\left(\mathrm{O}_{2}{ }^{\circ}\right)$ production (dihydroethidium, DHE assay) and apoptotic caspase-3,7 activities. The results provide the first reported systematic indications of the relationships between natural CKs' structures and neuroprotective activities.

\section{Results and Discussion}

\subsection{Cytokinins' Oxygen Radical Absorbance Capacity (ORAC)}

As neurodegenerative diseases are associated with elevated oxidative stress, antioxidant activity plays a key role in defenses of neuronal cells. To assess CKs' biological potential in this respect, antioxidant capacity was determined by ORAC, which is commonly used to determine substances' antioxidant capacity [28]. Antioxidant capacity was expressed as Trolox equivalents (TE), which determines the effectiveness (lower to higher) of compounds than Trolox on equimolar basis. The results, presented in Table 1, show that topolins (oT, $m$ T and $p$ T) and their ribosides (oTR, $m$ TR, $p$ TR) have high antioxidant activities, which are probably closely related to the electron-rich system of their C6-hydroxybenzylamino substituent. Despite their high ORAC values, the topolins did not have high neuroprotective activity. However, several heteroaromatic CKs including $\mathbf{K}\left(\mathrm{N}^{6}\right.$-furfurylaminopurine) and non-aromatic cis-zeatin-O-glucoside (cZOG), which has a 4-hydroxy-3-methylbut-2-en-1-yl)amino substituent, also showed high antioxidant capacity (Table 2). Other CK metabolites-including kinetin-3-glucoside (K3G), kinetin riboside $5^{\prime}$-monophosphate (KMP), kinetin-9-glucoside (K9G), and trans-zeatin riboside- $5^{\prime}$ monophosphate (tZMP) — had moderate antioxidant activity. All the others had detectable capacity except BAP. These results confirm previous findings that iP, $p$ T, $\mathbf{K}$ can act as direct radical scavengers, but conflict with previously reported activity of BAP in the ORAC test $[20,21]$. To conclude, these compounds have potential in the treatment of neurodegenerative diseases associated with increased oxidative stress [29].

\subsection{Differentiation of SH-SY5Y Cells}

To study CKs' neuroprotective effects, SH-SY5Y neuroblastoma cells (chosen for reasons already described [23]) were differentiated by exposure to $10 \mu \mathrm{M}$ ATRA for $48 \mathrm{~h}$ as previously described $[23,24]$. They were then stained using a membrane staining kit to examine morphological differences between undifferentiated and differentiated cells. As shown in Figure 1A, the neuron-like differentiated cells grew less densely, were more prolonged, and produced more neurites (indicated by yellow arrows in the figure) than the undifferentiated cells. These morphological changes associated with differentiation have been previously observed, even after shorter exposure (24 h) to ATRA [24,30]. More importantly, the number of neurites rises dramatically to a level when they can create a neurite network. From this reason, cell viability was measured to compare the rate of proliferation of undifferentiated and differentiated SH-SY5Y cells. The viability of undifferentiated SH-SY5Y was taken as the maximum rate of proliferation. The results present in 
Figure 1B show that proliferation rate (assessed by Calcein AM viability assay) of SH-SY5Y was reduced by $23 \%$ after $48 \mathrm{~h}$ ATRA treatment.
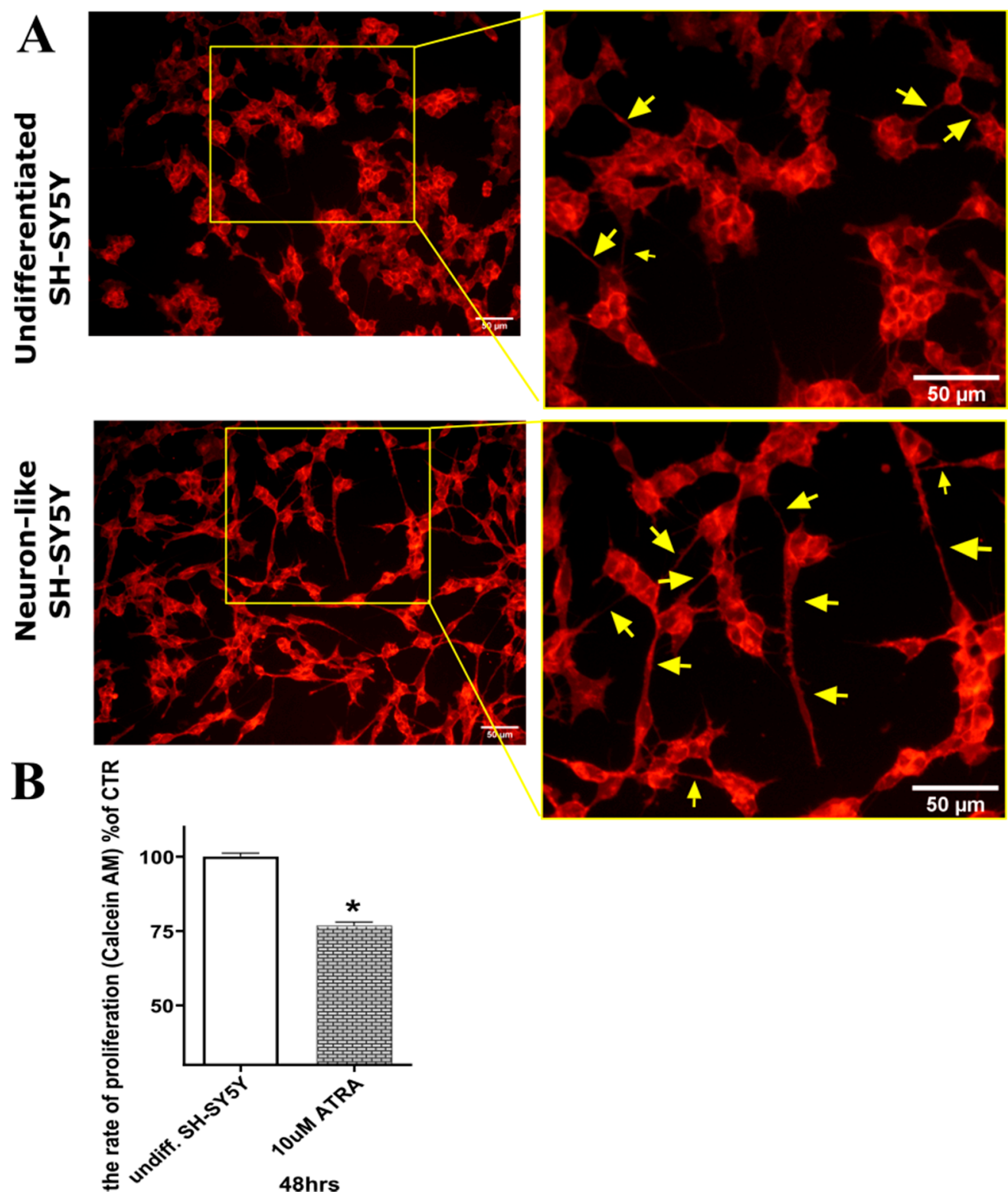

Figure 1. (A) Fluorescent micrographs of SH-SY5Y cells with membranes stained using a Neurite outgrowth kit (Invitrogen $^{\mathrm{TM}}$ ): Control, undifferentiated cells (exposed to mock treatment solution: $<0.1 \%$ DMSO); Cells differentiated by exposure to $10 \mu \mathrm{M}$ all-trans retinoic acid (ATRA) for $48 \mathrm{~h}$. Bars $=50 \mu \mathrm{m}$. (B) Proliferation rates of undifferentiated and differentiated SH-SY5Y cells: numbers of viable cells after $48 \mathrm{~h}$ exposure to $<0.1 \%$ DMSO and $10 \mu \mathrm{M}$ ATRA, respectively. Data were obtained from five independent experiments with triplicate cultures: asterisks show the significance of differences in numbers of viable cells (as percentages of numbers of undifferentiated cells) between the cultures: ${ }^{*} p<0.05$. 
Table 2. Oxygen radical absorbance capacity (ORAC) of the tested cytokinins (CKs) expressed as Trolox equivalents (TE) on an equimolar basis. Names, abbreviations, and structures of the CKs are presented in Figure 1.

\begin{tabular}{|c|c|c|c|c|c|}
\hline & Average (TE) & $\mathrm{SD}(n=3)$ & & Average (TE) & $\operatorname{SD}(n=3)$ \\
\hline$t Z$ & 0.073 & 0.012 & $\mathrm{~K}$ & 2.082 & 0.256 \\
\hline$t Z R$ & 0.13 & 0.012 & KR & 1.673 & 0.294 \\
\hline$t \mathrm{ZMP}$ & 0.326 & 0.017 & KMP & 0.726 & 0.026 \\
\hline$t Z 7 G$ & 0.082 & 0.006 & K3G & 0.53 & 0.035 \\
\hline$t Z 9 G$ & 0.063 & 0.004 & K9G & 0.906 & 0.025 \\
\hline$t \mathrm{ZOG}$ & 0.042 & 0.006 & BAP & $\mathrm{N} / \mathrm{A} *$ & $\mathrm{~N} / \mathrm{A} *$ \\
\hline$c Z$ & 0.151 & 0.009 & $o \mathrm{~T}$ & 7.026 & 1.179 \\
\hline$c Z R$ & 0.178 & 0.005 & oTR & 3.241 & 0.140 \\
\hline$c \mathrm{ZMP}$ & 0.173 & 0.036 & $m \mathrm{~T}$ & 4.509 & 0.687 \\
\hline$c Z 9 G$ & 0.085 & 0.009 & $m \mathrm{TR}$ & 3.171 & 0.239 \\
\hline$c Z O G$ & 3.301 & 0.036 & $p \mathrm{~T}$ & 16.799 & 0.829 \\
\hline iP & 0.384 & 0.005 & $p \mathrm{TR}$ & 4.147 & 0.238 \\
\hline iPR & 0.224 & 0.024 & & & \\
\hline
\end{tabular}

${ }^{*} \mathrm{~N} / \mathrm{A}-$ no antioxidant capacity was detected.

\subsection{Cytotoxicity of Cytokinins towards Neuron-like SH-SY5Y Cells}

In tests of the CKs' potential cytotoxicity with the Calcein AM viability assay [31] most showed low toxicity towards the neuron-like SH-SY5Y cells. The decrease of viability below $90 \%$ was considered as threshold for neurotoxic effect. The only two exceptions were KR $(11.9 \%)$ and $p$ TR $(10.5 \%)$, in accordance with previous findings that some cytokinin metabolites, particularly ribosides, may have cytotoxic effects [32]. Other ribosides, such as $c \mathbf{Z R}$, iPR, $o$ TR, $m$ TR, caused no apparent reduction in the neuron-like SH-SY5Y cells' viability (Table 3). DFO [33,34] and NEC-1 [35,36] used as positive controls in our in vitro model were also proved by other studies on SH-SY5Y cells to be non-toxic. In conclusion, mainly derivatives KR and $p$ TR showed lower viability than $90 \%$ and were therefore considered less interesting for further evaluation in both in vitro models of neurodegeneration.

Table 3. Cell viability of neuron-like SH-SY5Y cells after exposure to cytokinins for $24 \mathrm{~h}$. Viability is expressed as percentage of DMSO control.

\begin{tabular}{|c|c|c|c|}
\hline \multirow{2}{*}{ Compound } & Viability $^{a}$ & \multirow{2}{*}{ Compound } & \multirow{2}{*}{$\begin{array}{c}\text { Viability }^{a} \\
(\%, 10 \mu M)\end{array}$} \\
\hline & $(\%, 10 \mu \mathrm{M})$ & & \\
\hline$t Z$ & $102.3 \pm 2.20$ & $\mathrm{~K}$ & $97.9 \pm 1.81$ \\
\hline$t Z R$ & $98.8 \pm 1.82$ & KR & $88.1 \pm 3.09$ \\
\hline$t \mathrm{ZMP}$ & $101.5 \pm 4.59$ & KMP & $93.5 \pm 3.57$ \\
\hline$t \mathrm{Z7G}$ & $101.4 \pm 2.44$ & $\mathrm{~K} 3 \mathrm{G}$ & $99.8 \pm 1.13$ \\
\hline$t Z 9 G$ & $97.6 \pm 1.59$ & K9G & $98.3 \pm 1.11$ \\
\hline$t \mathrm{ZOG}$ & $94.3 \pm 1.67$ & BAP & $98.8 \pm 1.40$ \\
\hline$c Z$ & $104.0 \pm 1.79$ & $o \mathrm{~T}$ & $95.5 \pm 4.02$ \\
\hline$c \mathrm{ZR}$ & $100.0 \pm 1.23$ & $o \mathrm{TR}$ & $90.8 \pm 3.81$ \\
\hline$c \mathrm{ZMP}$ & $93.8 \pm 2.13$ & $m \mathrm{~T}$ & $90.4 \pm 6.03$ \\
\hline$c Z 9 G$ & $101.7 \pm 2.08$ & $m \mathrm{TR}$ & $99.5 \pm 3.69$ \\
\hline$c Z O G$ & $98.18 \pm 1.59$ & $p \mathrm{~T}$ & $90.6 \pm 3.25$ \\
\hline iP & $104.5 \pm 0.97$ & $p \mathrm{TR}$ & $89.5 \pm 3.89$ \\
\hline iPR & $96.9 \pm 3.25$ & & \\
\hline NAC (1 mM) & $90.2 \pm 5.06$ & DFO $(100 \mu \mathrm{M})$ & $102.1 \pm 4.22$ \\
\hline NEC-1 $(50 \mu \mathrm{M})$ & $95,8 \pm 3.75$ & & \\
\hline
\end{tabular}

\subsection{Identification of Neuroprotective Cytokinins in the SAL-induced Model of PD}

For these tests, neuronal SH-SY5Y cells were differentiated for $48 \mathrm{~h}$ then co-treated with $500 \mu \mathrm{M}$ SAL and each CK at three concentrations $(0.1,1,10 \mu \mathrm{M})$. As shown by the dot- 
ted line in Figure 2A, application of the neurotoxin SAL at $500 \mu \mathrm{M}$ reduced the viability of differentiated SH-SY5Y cells, according to the Calcein AM assay, by $30 \%$. N-acetylcysteine (NAC) was used as a positive control in these tests due to its previously reported neuroprotective effect in the same SH-SY5Y cell-based in vitro model [37]. Concentrations of 10, 100 , and $1000 \mu \mathrm{M}$ NAC were used to induce partial or almost complete recovery in the SAL-model. NAC was able to increase cell viability at $100 \mu \mathrm{M}$ and $1 \mathrm{mM}$ concentration, corresponding to $83.39 \pm 1.74 \%$ and $89.21 \pm 2.89 \%$, respectively. NAC's protective activity at $100 \mu \mathrm{M}$ (indicated by the dashed line in Figure 2A) was used as a potency threshold for selecting CKs for further tests. According to this setup, the biologically significant neuroprotective activities have been observed with $\mathrm{K} 3 \mathrm{G}$ at $10 \mu \mathrm{M}(81.84 \pm 2.36 \%), c Z R$ at $0.1 \mu \mathrm{M}$ $(81.14 \pm 2.30 \%)$ and $1 \mu \mathrm{M}(81.53 \pm 2.24 \%)$ and $\mathbf{i P R}$ at $1 \mu \mathrm{M}(82.43 \pm 2.51 \%)$. Thus, iPR and cZR were effective neuroprotectants at lower micro or sub-micromolar concentrations than NAC. The cytokinin screening also revealed that many other metabolites can moderately increase the viability of differentiated SH-SY5Y cells exposed to SAL. However, some tested CKs (including $t \mathrm{ZR}, t \mathrm{ZMP}, m \mathrm{~T}, m \mathrm{TR}, \mathrm{pT}$, and $p \mathrm{TR}$ ) had very little protective effect.

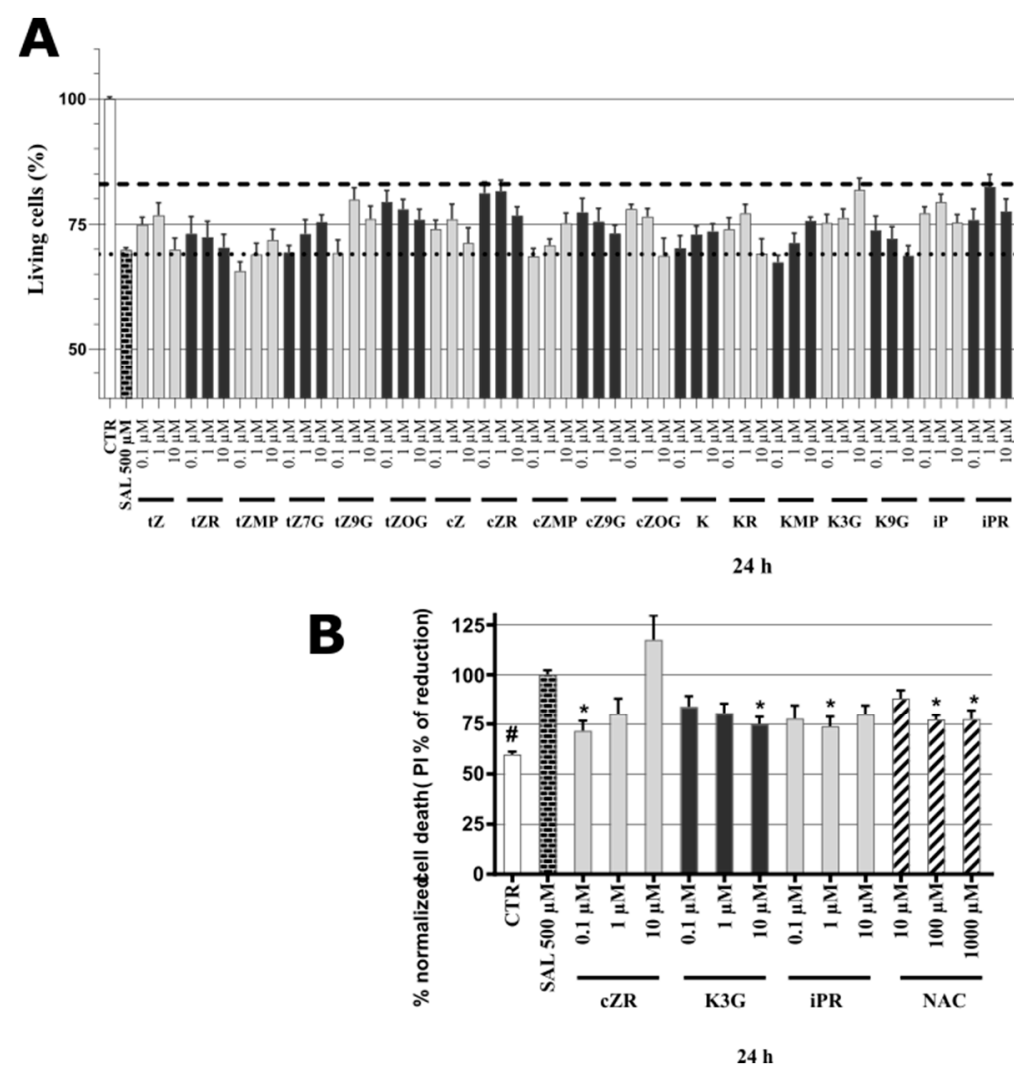

Figure 2. (A) Neuroprotective activity of cytokinins and N-acetylcystein (NAC) in SAL-induced model of PD on neuron-like SH-SY5Y cells. The dashed line shows the NAC effect threshold at which cytokinins were selected for further testing; the dotted line then counts the number of living cells in the Calcein AM assay after treating the cells with $500 \mu \mathrm{M}$ SAL; healthy control cells (CTR, DMSO < 0.1\%). Triplicates in at least three separated days. (B) Normalized SH-SY5Y cell death after propidium iodide staining. Triplicates in at least five independent days. ${ }^{*} P$ compared with vehicle with $500 \mu \mathrm{M}$ SAL, \# P compared with vehicle without $500 \mu \mathrm{M}$ SAL.

To confirm the most active natural CKs' anti-PD activities, overall cell death rates were quantified by propidium iodide (PI) staining, which (in contrast to cell metabolism-based viability tests) only labels cells with impaired membrane integrity, dying cells, and already dead cells [38]. Results were normalized with respect to the cell death rate following treatment with SAL alone (set as 100\%). As shown in Figure 2B, the NAC positive control substance significantly reduced cell death rates at both 100 and $1000 \mu \mathrm{M}$ (to $77.3 \pm 2.21 \%$ and $77.5 \pm 4.44 \%$, respectively). Overall, NAC proved to be a neuroprotective agent with 
comparable activities to those recorded in other studies in a dose-dependent manner (in the 50-500 $\mu \mathrm{M}$ range) for SH-SY5Y cells [37]. The PI assay also showed that the CKs cZR, K3G, and iPR have protective activities, especially $c \mathbf{Z R}$, which reduced the cell death rate to $71.6 \pm 5.08 \%$ at $0.1 \mu \mathrm{M}$. In contrast to $c \mathbf{Z R}, \mathbf{K} 3 \mathrm{G}$ had reversed dose-dependent effects, with maximum activity at $10 \mu \mathrm{M}$ (reducing the cell death rate to $75.0 \pm 3.69 \%$ ) and iPR's activity peaked at $1 \mu \mathrm{M}$ (reducing the rate to $73.9 \pm 4.99 \%$ ). Taken together, as shown in Figure 2, CKs provided comparable neuroprotective activity to $100 \mu \mathrm{M}$ NAC according to both the viability and cytotoxicity assays. Moreover, effective concentrations of CKs such as cZR and iPR were much lower than those of NAC, in the sub-micromolar and micromolar ranges. Previous observations obtained following double staining with PI and annexin $\mathrm{V} / \mathrm{PI}$ indicate that $\mathbf{K}$ may reduce apoptosis [39], thus we also investigated effects of CKs and NAC on oxidative stress and caspase-3,7 activation (a well-known apoptosis marker).

\subsection{Cytokinins Decrease SAL-induced Superoxide Radical Formation}

Oxidative stress (OS) is a key pathological contributor to several neurodegenerative diseases, and both SAL (at $>100 \mu \mathrm{M}$ ) and tetrahydroisoquinolines are potent OS inducers $[26,40]$. Thus, we also measured formation of superoxide (a ROS and important OS marker) in the presence of SAL with and without selected CKs or NAC. To ensure that SAL caused sufficient OS damage in SH-SY5Y cells to detect responses, cells were exposed to $500 \mu \mathrm{M}$ SAL for $24 \mathrm{~h}$, as in previous work [37] and in accordance with findings presented above. The cells were then stained by dihydroethidium (DHE) to detect superoxide radical formation [41,42]. As can be seen in Figure 3A, cells were visually observed after labelling with DHE (which provides red fluorescence signals following reaction with superoxide). SAL induced a clear rise in DHE fluorescence, relative to levels in control and NAC-treated cells. Moreover, three CKs (cZR, K3G, and iPR) had similar visual effects to NAC (100 $\mu$ M) on DHE fluorescence. Furthermore, the spectrophotometric quantification with respect to levels detected in cells treated by SAL alone (set as 100\%), was in line with microscopy observation. As shown in Figure 3B, the normalized superoxide level in healthy control cells (CTR) was less than 39\%, and the positive control substance NAC provided moderateto-complete reduction of SAL-induced ROS production at 100 and $1000 \mu \mathrm{M}$ (to $76.3 \pm 4.33$ and $44.3 \pm 5.12 \%$ ), suggesting that glutathione (GSH) depletion plays a key role in the model [26]. Interestingly, SAL induced dramatic reductions in GSH contents of SH-SY5Y cells accompanied by elevation of OS, to levels similar to those previously observed in a study that also recorded NAC-mediated effects on cell viability, cell death, and glutathione contents [43]. Results presented here show that NAC also reduced superoxide radical formation to basal levels (i.e., levels in DMSO-treated controls). CK ribosides were tested at active concentrations $(0.1-1 \mu \mathrm{M})$ along with $\mathrm{K} 3 \mathrm{G}$, and significantly reduced the cells' superoxide radical contents to the following levels (relative to those of cells treated with SAL alone): $c$ ZR $80.34 \pm 5.99 \%$ at $0.1 \mu \mathrm{M}$; K3G $77.1 \pm 4.89 \%$ at $10 \mu \mathrm{M}$; iPR $79.2 \pm 5.91 \%$ at $1 \mu \mathrm{M}$, comparable to the effects of $100 \mu \mathrm{M}$ NAC. Collectively, the orthogonal demonstrations strongly indicate that potent anti-OS activity plays a key role in the protective effects of NAC and CKs in the SAL-induced PD model. A correlation between OS amelioration and neuroprotection has also been noted by other authors [29], and several studies have found that $\mathbf{K}$ and BAP can directly ameliorate OS activities [44] through formation of complexes with $\mathrm{Cu}^{2+}$ ions, resulting in superoxide dismutase-like activity $[45,46]$. However, $\mathrm{CKs}$ have also been described as indirect antioxidants with effects mediated by induction of the nuclear factor erythroid 2-related factor 2 (NRF2) antioxidant response pathway (iPR) [22] or partial restoration of glutathione peroxidase and SOD activities (K) [16]. In addition, $K$ reportedly has neuroprotective activities against $\mathrm{OS}$ injury induced by $\mathrm{H}_{2} \mathrm{O}_{2}$ in $\mathrm{SH}$ SY5Y cells [17]. Both types of reported anti-ROS activity of CKs could potentially explain to effects of $c \mathbf{Z R}, \mathbf{K} 3 \mathrm{G}$, and $\mathbf{i P R}$ in reduction of superoxide radicals in the SAL-induced SH-SY5Y cell PD model [47-50]. 


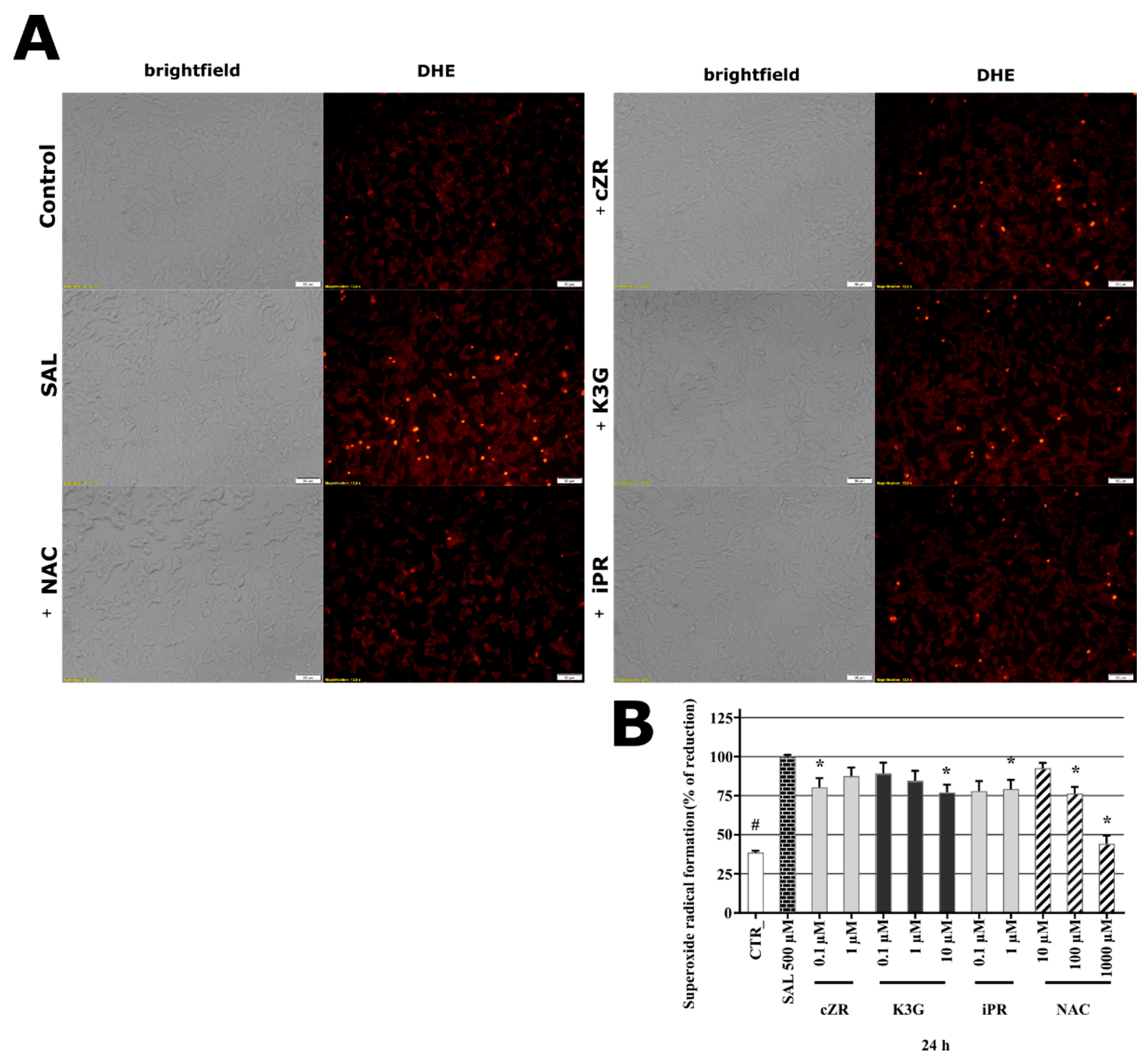

Figure 3. (A) Microphotographs showing SAL-induced oxidative stress and oxidative stress-reducing activities of cytokinins in human differentiated neuron-like SH-SY5Y cells visualized by fluorescence microscopy following dihydroethidium (DHE) labelling. Bars $=50 \mu \mathrm{m}$. The images show cells treated with DMSO solution (controls), $500 \mu \mathrm{M}$ salsolinol (SAL) alone, and combinations of $500 \mu \mathrm{M}$ SAL and $1000 \mu \mathrm{M}$ NAC (+NAC), $0.1 \mu \mathrm{M} c \mathbf{Z R}(+c \mathbf{Z R}) ; 10 \mu \mathrm{M} \mathrm{K3G}(+\mathbf{K} 3 \mathrm{G}), 1 \mu \mathrm{M}$ iPR (+iPR) for $24 \mathrm{~h}$ before staining with DHE. (B) SAL-induced superoxide radical formation and cytokinin or $N$-acetylcysteine (NAC) protective activity. The graph shows the quantification of DHE stained cells using Infinite M200 Pro microplate reader (Tecan, Austria). Triplicates in at least five independent days. ${ }^{*} P$ compared with vehicle with $500 \mu \mathrm{M}$ SAL, \# P compared with vehicle without $500 \mu \mathrm{M}$ SAL.

\subsection{Anti-Apoptotic Effects of Cytokinins Determined by Caspase-3/7 Activity Measurements}

As shown by the PI staining assays described above, SAL induced increases in the SH-SY5Y cells' death rates. As SAL is associated with both apoptosis and necrosis [51] we also investigated the activation of caspase-3 and 7 (casp-3/7) as a specific marker of apoptosis (the execution phase) [52] after exposing the cells to CKs. Caspase-3/7 activities recorded following treatment with each of the test compounds were normalized with respect to those recorded following treatment with $500 \mu \mathrm{M}$ SAL (set as 100\%). As shown in Figure 4, the well-known caspase inhibitor Ac-DEVD-CHO (included as a specific, apoptosis-related control) strongly inhibited caspase-3/7 activity at sub-micromolar concentrations (to $36.3 \pm 2.66$ and $25.2 \pm 2.69 \%$ of levels in cells treated with SAL alone 
at 0.05 and $0.5 \mu \mathrm{M}$, respectively). Similar levels of inhibition have been previously observed [53] in different in vitro SH-SY5Y cell-based models of neurodegeneration. The positive control NAC also significantly reduced caspase- $3 / 7$ activity, to $88.7 \pm 1.87 \%$ and $78.5 \pm 2.56 \%$ of SAL-induced levels at $100 \mu \mathrm{M}$ and $1000 \mu \mathrm{M}$, respectively. The tested CKs had a wide array of effects on caspase-3/7 activities. Interestingly from the CK ribosides, only $c$ ZR had significant effects on the activities at $0.1 \mu \mathrm{M}$ (reducing them to $83.3 \pm 4.33 \%$ of SAL-induced levels, respectively), while iPR at $1 \mu \mathrm{M}$ did not significant reduction of casp-3,7. Finally, K3G decreased caspase-3/7 activity with maximum effect at $10 \mu \mathrm{M}$ (to $81.7 \pm 4.31 \%$ of the SAL-induced level). Overall, SAL-induced a 1.6-fold increase in caspase-3/7 activity compared to healthy control cells (CTR, Figure 4), in accordance with results of an earlier study, in which a similar SAL concentration $(400 \mu \mathrm{M})$ and the same cell line were used [54]. NAC is known to influence caspase-3/7 activity in several models of neuronal death [55-58]. However, results presented here provide the first demonstration of their caspase-3/7 in an SH-SY5Y cell-based SAL-induced model of neuronal death. The positive control reduced the caspase-3/7 activity induced by $500 \mu \mathrm{M}$ SAL in a similar manner to CKs, but $c$ ZR and K3G were effective even at sub-micromolar or micromolar concentrations. Other studies with stress models associated with PD (proteasome inhibitor MG 132- or $\mathrm{H}_{2} \mathrm{O}_{2}$-induced toxicity in SH-SY5Y cells [17] and fibroblasts [15]) and Huntington's disease (serum starvation model in PC12 cells [19]) have also shown that the CKs $\mathbf{K}$ and $\boldsymbol{t Z \mathbf { R }}$ can have anti-apoptotic (caspase-3) activities [17], and that both $\mathbf{K}$ and $\boldsymbol{t Z \mathbf { R }}$ can have anti-senescence activities [17,19]. Moreover, associations between decreasing of casp-3,7 activation and neuroprotective activity was reported for SAL and SAL-related models $[54,59,60]$.

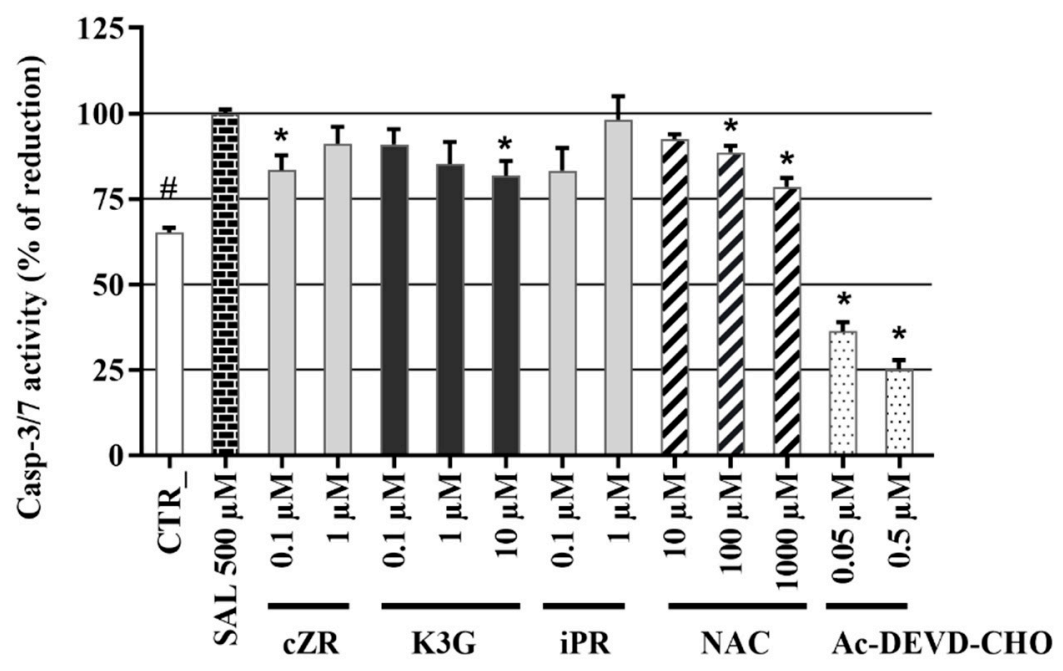

$24 \mathrm{~h}$

Figure 4. Caspase-3/7 activity in the SAL-induced model of PD. Triplicates in at least four independent days. ${ }^{*} P$ compared with vehicle with $500 \mu \mathrm{M}$ SAL, \# P compared with vehicle without $500 \mu \mathrm{M}$ SAL.

\subsection{Identification of Cytokinin Neuroprotective Activity in the Glutamate-induced Cell Death Model}

As SH-SY5Y cells do not express all NMDA receptor subunits [61], the most likely mechanism of glutamate (Glu) toxicity is blockage of the cystine/glutamate Xc-antiporter with massive induction of oxidative stress [62]. Previous authors have already demonstrated an association between glutamate-induced cell death and necroptosis in SH-SY5Y cells [63], and the importance of caspase- 3 activation in glutamate-induced toxicity towards them $[62,64]$. Several studies have also shown the occurrence of iron-driven cell death (ferroptosis) after glutamate intoxication $[62,65,66]$, and indicated the occurrence of three types of cell death (necroptosis, apoptosis, and ferroptosis) following blockade 


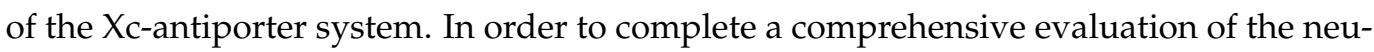
roprotective potential of the tested cytokinins, the glutamate-induced cell death assay system was included in an analytical panel with the known neuroprotective iron chelator deferoxamine (DFO) and inhibitor of necroptosis necrostatin-1 (NEC-1) [67] as positive controls. Here, SH-SY5Y cells were differentiated for $48 \mathrm{~h}$, then treated with $160 \mathrm{mM}$ Glu or in co-treatment thereof with various cytokinin concentrations $(0.1-10 \mu \mathrm{M})$ for $24 \mathrm{~h}$ and stained by PI. In this model, the effect of Glu on cell death was $100 \%$ PI signal, so the reduction in cell death by the test compounds was evaluated. Glu induced almost a 4-fold increase in cell death compared to healthy SH-SY5Y controls $(26.1 \pm 0.42 \%)$. Screening of positive controls and cytokinins revealed that both positive controls NEC-1 (50 $\mu \mathrm{M}$, $76.6 \pm 2.51 \%)$ and DFO $(10 \mu \mathrm{M}, 84.2 \pm 4.54 \%)$ decreased the cell death induced by glutamate. As shown in Figure 5A, from the panel of cytokinins, only three cytokinins were able to protect neuron-like SH-SY5Y cells in similar fashion as positive controls. The most active cytokinins were trans-zeatin $(t \mathrm{Z})(0.1 \mu \mathrm{M}, 79.5 \pm 2.91 \% ; 1 \mu \mathrm{M}, 81.3 \pm 2.77 \%)$ and cis-zeatin $(c Z)(0.1 \mu \mathrm{M}, 82.1 \pm 3.29 \% ; 1 \mu \mathrm{M}, 86.2 \pm 2.89 \%)$ and kinetin $(\mathbf{K})(1 \mu \mathrm{M}$, $88.0 \pm 3.76 \% ; 10 \mu \mathrm{M}, 79.9 \pm 3.44 \%)$. To confirm their promising activity, an orthogonal assay was used to elucidate in more detail $\mathrm{CKs}^{\prime}$ biological effects in this model: A lactate dehydrogenase (LDH)-release assay [68], which also showed a dramatic (4-fold) increase in toxicity following Glu treatment. Interestingly, the determination of LDH-release allowed us to differentiate between activities of CKs and the positive controls (NEC-1 and DFO). The CKs had moderate but significant protective activity ( $t \mathrm{Z}$ reduced the death rates to $91.9 \pm 1.40 \%$ at $0.1 \mu \mathrm{M} ; c \mathrm{Z}$ reduced them to $92.3 \pm 1.15 \%$ at $0.1 \mu \mathrm{M}$ and $91.7 \% \pm 1.56 \%$ at $1 \mu \mathrm{M} ; \mathrm{K}$ reduced them to $92.2 \pm 1.06 \%$ at $1 \mu \mathrm{M}$ ). The positive controls NEC-1 and DFO had stronger protective effects but were effective at much higher concentrations (reducing the rates to $76.9 \pm 2.94 \%$ and $81.6 \pm 3.74 \%$ at 50 and $10 \mu \mathrm{M}$, respectively) (Figure $5 \mathrm{~B}$ ). The LDH assay validated the indications obtained with PI staining and observed effects of the positive controls were consistent with published data $[69,70]$. Findings regarding effects of $\mathbf{K}$ in Glu-induced cell death model in HT22 cells [18] and our observations of effects of representative $C K s$ such as $t Z, c Z$, and $K$ show that $C K s$ are promising candidates for treating neurodegenerative diseases associated with oxidative stress [71]. Finally, $t \mathbf{Z}$ and $c \mathbf{Z}$ were preferred because they were effective at lower concentrations and were selected, together with $\mathbf{K}$, for further studies of their effects on levels of oxidative stress and caspase-3,7 activation.

\subsection{Effects of Cytokinins on Glu-induced Oxidative Stress in SH-SY5Y cells}

Unlike the previous model, Glu can induce oxidative stress in SH-SY5Y cells by different pathways. One is based on blockage of the Cystine/glutamate (Xc-) antiporter, which leads to glutathione (GSH) depletion and negative effects on superoxide dismutase (SOD) activity [62]. Glu-mediated cell death also putatively involves Rac-NADPH-oxidase-driven ROS (particularly superoxide radical) formation in SH-SY5Y cells [72]. These findings indicate that the primary cause of cell death in the Glu-induced model is OS. Within the model, neuron-like cells were co-treated with Glu and tested compounds, stained by DHE, and observed by fluorescence microscopy. As can be seen in Figure 6A, a dramatic rise in red DHE fluorescence was observed in Glu-treated cells, which was ameliorated by the positive control substances and tested CKs. Based on the microscopy observation, the quantification of superoxide levels was performed in Glu-induced cells in a similar manner, by the DHE assay, to those in SAL-induced cells. The results were normalized with respect to levels induced by Glu alone (set as 100\%), which caused a dramatic, almost 3-fold increase in superoxide levels within just $4 \mathrm{~h}$ in neuron-like SH-SY5Y cells relative to levels in healthy control cells (CTR: $33.79 \pm 1.45 \%$ ). As shown in Figure $6 \mathrm{~B}, \mathrm{CKs}$ such as $t \mathbf{Z}, c \mathbf{Z}$, and $\mathrm{K}$ significantly reduced the superoxide level in Glu-intoxicated cells: $0.1 \mu \mathrm{M}$ $t \mathrm{Z}, 0.1 \mu \mathrm{M} c \mathrm{Z}, 1 \mu \mathrm{M}$ and $10 \mu \mathrm{M} \mathrm{K}$ reduced it to $81.0 \pm 4.03,80.6 \pm 3.89,81.8 \pm 3.39$ and $83.8 \pm 2.32 \%$ of levels in cells treated with Glu alone. These levels are comparable to those obtained with the necroptosis inhibitor NEC-1 $(80.5 \pm 3.19 \%$ at $5 \mu \mathrm{M}$ and $80.4 \pm 2.70 \%$ 
at $50 \mu \mathrm{M})$ and iron-chelator DFO $(80.2 \pm 3.80 \%$ at $10 \mu \mathrm{M})$. The results obtained with the Glu-induced cell death model, particularly the effects of positive controls, are consistent with previous reports [70,73]. Previous evidence that CKs have OS-reducing effects in Glu-induced or similar models is limited to a demonstration that $\mathbf{K}$ is a potent OS-reducing agent (at approximately $23 \mu \mathrm{M}$ ) in the HT22 cell-based Glu-induced cell death model [18]. We found that $\mathbf{K}$ had an OS-reducing effect at lower concentrations (1-10 $\mu \mathrm{M})$ in our SHSY5Y cells. In addition, beneficial long-term effects of $t Z$ on human fibroblasts, including hydrogen peroxide-decomposing activity, have been observed [15], suggesting that $t Z$ and $c \mathbf{Z}$ may have indirect OS-reducing effects in Glu-induced cell death models. Additionally, other reports pointed out the associations between CKs-mediated OS-reducing effect and protective activity [22,74-76]. Taken together, $\mathbf{t Z}, \boldsymbol{c Z}$, and $\mathbf{K}$ showed surprisingly strong OS-reducing effects, comparable to those of positive controls, despite differing strengths in overall neuroprotective effect.

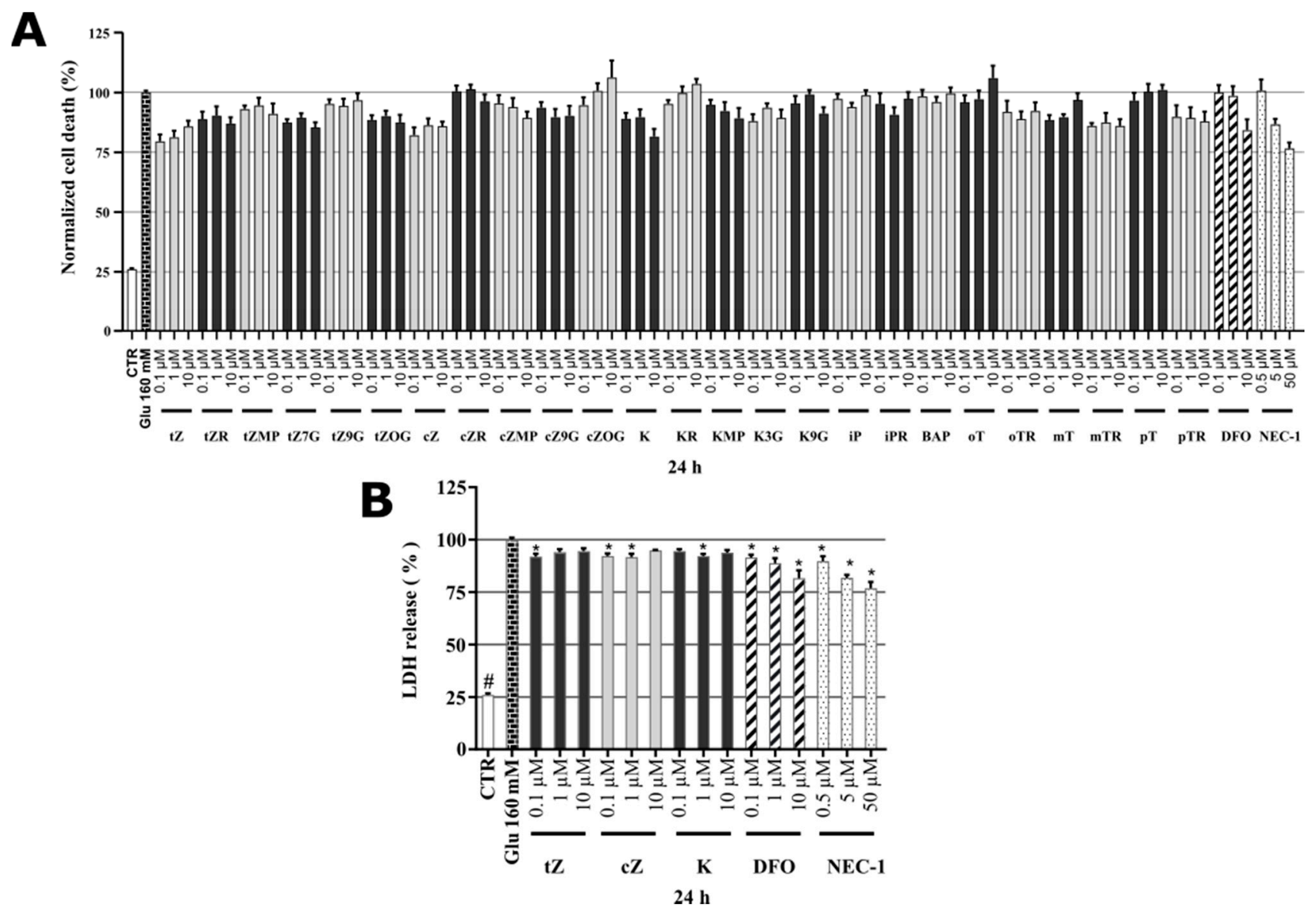

Figure 5. (A) Death rate of neuron-like SH-SY5Y cells in glutamate (Glu)-induced model of cell death; (B) Glu-induced toxicity (LDH-release) of neuron-like SH-SY5Y cells. Triplicates in at least three independent days. ${ }^{*}$ compared with vehicle with $160 \mu \mathrm{M}$ Glu, \# P compared with vehicle without $160 \mu \mathrm{M}$ Glu. 


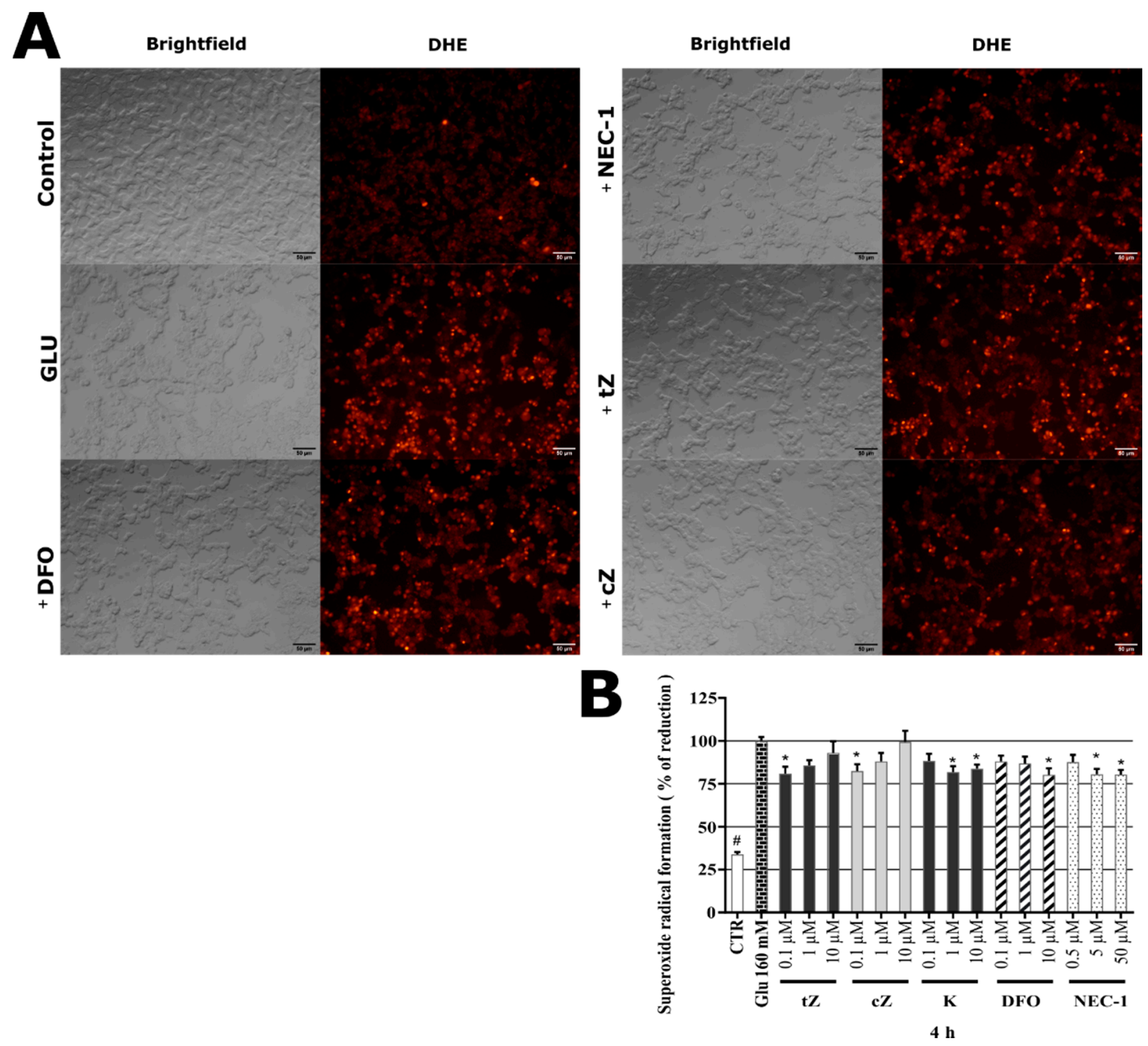

Figure 6. (A) Glu-induced oxidative stress (OS) and OS-reducing activity of indicated compounds in human neuron-like SH-SY5Y cells visualized by fluorescence microscopy following dihydroethidium (DHE) labelling. Bars $=50 \mu \mathrm{m}$. Images show neuron-like SH-SY5Y cells treated by DMSO (Control), $160 \mathrm{mM}$ glutamate (Glu) alone, and together with: $10 \mu \mathrm{M}$ deferoxaine (+DFO), $50 \mu \mathrm{M}$ necrostatin-1 (+NEC-1), $0.1 \mu \mathrm{M} t \mathbf{Z}(+t \mathbf{Z})$ and $0.1 \mu \mathrm{M} c \mathbf{Z}(+c \mathbf{Z})$ for $4 \mathrm{~h}$, then stained by DHE. (B) Glu-induced superoxide radical formation in neuron-like SH-SY5Y cells after $4 \mathrm{~h}$. The graph displays the quantification of DHE stained cells using Infinite M200 Pro microplate reader (Tecan, Austria). Triplicates in five independent days. * P compared with vehicle with $160 \mu \mathrm{M}$ Glu, \# P compared with vehicle without $160 \mu \mathrm{M}$ Glu.

\subsection{Effects of Cytokinins on Caspase-3/7 Activity in the Glu-induced Cell Death Model}

Glu has similar toxic effects on SH-SY5Y cells to previously reported effects on HT22

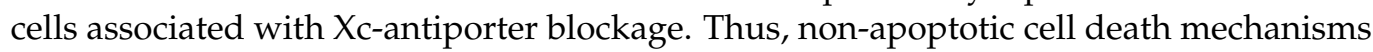
(ferroptosis, necroptosis, etc.) are involved in both cases [62] although expression of caspase-3 and to some degree the NMDA subunit of NR1 may be more strongly occurred in SH-SY5Y cells [61]. Hence, final stages of cell death in the two cell lines may differ. A contributory role of caspase-3 activity has been observed in many studies in the Gluinduced model of cell death of SH-SY5Y cells [62,77-79]. In this assay, neuron-like SH-SY5Y cells were treated here with $160 \mathrm{mM}$ Glu, which leads to elevation of caspase-3/7 activity. In efforts to elucidate the role of apoptosis in Glu-induced death of SH-SY5Y cells, a specific caspase-3/7 inhibitor, Ac-DEVD-CHO, was applied and found to have strong inhibitory effect: At $50 \mathrm{nM}$ it reduced caspase-3,7 activity to $23.70 \pm 1.01 \%$ of the level in cells treated 
with Glu alone and at $0.5 \mu \mathrm{M}$ it almost completely blocked the activity (reducing it to a normalized level of just $7.22 \pm 1.05 \%$; comparable to the level observed in healthy cells: $7.8 \pm 0.39 \%$ ), as shown in Figure 7. Application of positive controls resulted in a gradual dose-dependent decrease in caspase-3,7 activity. Interestingly, NEC-1 had a slight effect with maximum effect at $50 \mu \mathrm{M}$ and DFO had more robust inhibitory activity at $10 \mu \mathrm{M}$ (reducing the activity to $80.5 \pm 1.85$ and $75.8 \pm 3.00 \%$, respectively). On the other hand, only slight, but significant effects on casp-3,7 were achieved by $t Z$ at $1 \mu \mathrm{M}(89.5 \pm 2.50 \%), c Z$ at $0.1 \mu \mathrm{M}(87.4 \pm 1.62 \%)$ and $\mathrm{K}$ at $1 \mu \mathrm{M}(91.0 \pm 2.06 \%)$. Taken together, the results show that both positive controls had stronger caspase-3/7 activity-decreasing activity than the tested $\mathrm{CKs}$, but the $\mathrm{CKs}$ had effects at much lower concentrations. Overall, the results indicate that modulation of caspase-3/7 activity plays a key role in the potent neuroprotective activity of agents such as DFO [58] in the Glu-induced model of cell death [79,80]. However, as shown in this section, NEC-1 also had neuroprotective activity, suggesting that other types of cell death might be involved in Glu-induced death of neuron-like SH-SY5Y cells $[63,67,81]$. Indications that caspase-independent mechanisms are involved in Glu-induced cell death have also been obtained in analyses of effects of NEC-1 [70], DFO [69], and K [18] on HT22 cells.

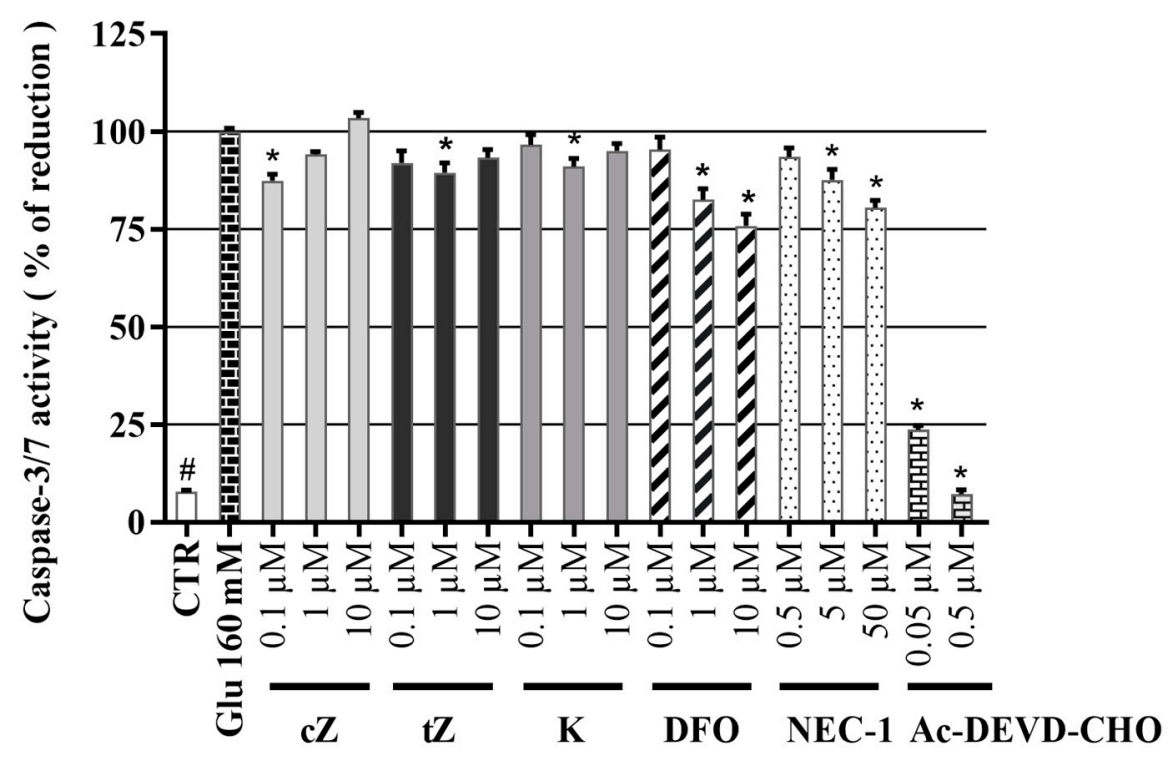

$1 \mathbf{h}$

Figure 7. Caspase-3/7 activity in Glu-model of oxidative damage of neuron-like SH-SY5Y cells. Triplicates in at least four independent days. ${ }^{*} P$ compared with vehicle with $160 \mu \mathrm{M}$ Glu, \# P compared with vehicle without $160 \mu \mathrm{M}$ Glu.

\section{Conclusions}

In summary, our study revealed that CKs and their metabolites have neuroprotective activities in the SAL-induced model of Parkinson's disease and Glu-induced oxidative damage in human differentiated SH-SY5Y neuronal cells. K3G, cZR, and iPR were found to have biologically significant neuroprotective activities. Moreover, the active CKs were effective at lower (sub-micromolar and micromolar) concentrations than the positive control substance NAC. K3G, $c$ ZR and iPR also had positive effects on viability, cytotoxicity, oxidative stress and caspase-3,7 activity (except iPR). The orthogonal demonstrations strongly indicate that anti-oxidative stress activity plays a key role in $\mathrm{CKs}^{\prime}$ protective effects in the SAL-induced cell death model. Only three metabolites in the tested panel of $\mathrm{CKs}(\boldsymbol{t Z}, c \mathbf{Z}$, and $\mathbf{K}$ ) protected neuron-like SH-SY5Y cells in the Glu-induced model of oxidative damage in a similar fashion to the iron chelator NEC1 and necroptosis inhibitor DFO. To confirm their promising activity, we tested their effects in an orthogonal lactate dehydrogenase 
(LDH)-release assay. The CKs had moderate but significant protective activity. This was weaker than corresponding activities of the control substances, but despite the differences in modulation of neuronal health, all three tested CKs stimulated potent reductions in superoxide radical formation, similarly to the positive control substances. The CKs also had comparable effects on Glu-induced oxidative stress in SH-SY5Y cells to those of NEC1 and DFO, but these compounds had stronger inhibitory effects on caspase- $3 / 7$ activity than the CKs. As Glu-induced cell death does not rely on a caspase-dependent pathway, as shown in studies of effects of DFO and NEC-1 on HT-22 cells [70], CKs can apparently modulate both caspase-dependent and -independent cell death by reducing oxidative stress [18,82]. In ongoing studies, the detailed mechanism of action of CKs and/or their mitochondrial effects on neuronal or astrocyte cells will be investigated.

\section{Materials and Methods}

\subsection{Chemicals and Reagents}

Cytokinin standards were obtained from OlChemIm (Olomouc, Czech Republic). Calcein AM $(1 \mathrm{mg} / \mathrm{mL}$ solution), an LDH release kit and a Neurite outgrowth kit were purchased from ThermoFisher. Propidium iodide, dihydroethidium, components of caspase3/7 assay buffer, DMEM/F12 1:1 medium, fetal bovine serum, trypsin, ATRA, salsolinol hydrobromide, glutamate monosodium salt, deferoxamine, $\mathrm{N}$-acetylcysteine, Ac-DEVD-CHO, and DMSO for cell cultures were purchased from Sigma Aldrich (Merck). Ac-DEVD-AMC substrate was supplied by Enzo Life Science.

\subsection{ORAC Radical Scavenging Activity Assays}

Compounds' ability to scavenge free radicals in vitro was determined by the Oxygen Radical Absorbance Capacity (ORAC) assay. Briefly, fluorescein $(100 \mu \mathrm{L}, 500 \mathrm{mM})$ and $25 \mu \mathrm{L}$ of tested compound solution was added to a 96-well microplate pre-incubated at

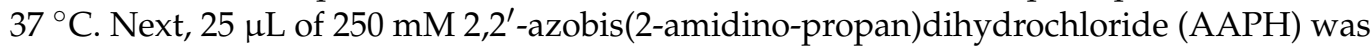
quickly added, the microplate was shaken for $5 \mathrm{~s}$ and red fluorescence (with 485 and $510 \mathrm{~nm}$ excitation and emission wavelengths, respectively) was measured every 3 min over 90 min using an Infinite 200 microplate reader (TECAN, Männedorf, Switzerland). NAUC (Net Area Under Curve) values were used to express antioxidant activities relative to that of Trolox (a synthetic hydrophilic analogue of $\alpha$-tocopherol, vitamin E). Substances with ORAC values greater than zero are deemed to actively trap free radicals.

\subsection{SH-SY5Y Cell Culture}

The human neuroblastoma cell line SH-SY5Y purchased from ATCC (American Type Culture Collection, Manassas, VA, USA) was grown in Dulbecco's modified Eagle's Medium and Ham's F12 Nutrient Mixture (DMEM:F-12, 1:1), supplemented with 10\% fetal bovine serum (FBS) and $1 \%$ penicillin and streptomycin at $37^{\circ} \mathrm{C}$ in a humidified $5 \%$ $\mathrm{CO}_{2}$ atmosphere. Cells were passaged up to 20 times and media were changed twice or thrice a week. Cell density was set as appropriate for the planned assay $(5000,7000,10,000$, or 20,000 cells per well) in 96-multiwell plates in $100 \mu \mathrm{L}$ total volumes of medium for each experiment. The day after the seeding, ATRA in 1\% FBS DMEM/F12 medium was added to the cells to a final concentration of $10 \mu \mathrm{M}$ and incubation was continued for a further $48 \mathrm{~h}$ to induce differentiation, allow formation of longer neurites, and reduce proliferation.

\subsection{Microscopy}

Micrographs of neuron-like SH-SY5Y cells were obtained using a DM IL LED fluorescence microscope (Leica Microsystems, Mannheim, Germany) with an appropriate excitation filter for the assay, or a brightfield setup with a DP73 high-performance digital camera (Olympus, Tokyo, Japan). Since the signal-to-noise ratio for staining was moderate, the contrast was slightly adjusted in ImageJ software (Fiji) without affecting the resulting observation. Original images are included in the Supplementary Materials. 


\subsection{Cell Membrane Staining (Neurite Outgrowth kit, Invitrogen ${ }^{\mathrm{TM}}$ )}

Neuron-like SH-SY5Y cells (5000 cells per well) obtained by the $48 \mathrm{~h}$ differentiation procedure were stained by a Neurite outgrowth kit (Invitrogen ${ }^{\mathrm{TM}}$ ) according to the manufacturer's recommendations with minor modification. The cells were washed with PBS, labelled with a solution of the membrane staining dye supplied with the kit (following the protocol for 96 multiwell plates) in PBS for 20 min at $37^{\circ} \mathrm{C}$, washed again with PBS and viewed under a fluorescence microscope (with 533 and $585 \mathrm{~nm}$ excitation and emission wavelengths, respectively).

\subsection{Cell Treatment}

After the differentiation procedure, the differentiation media was changed to $1 \%$ DMEM/F12 medium supplemented with test compounds at concentrations of $0.1,1$, and $10 \mu \mathrm{M}$ (with 7000 cells per well for cytotoxicity tests), or together with the toxin SAL at $500 \mu \mathrm{M}$ (with 7000-10,000 cells per well) or $160 \mathrm{mM}$ Glu (with 20,000 cells per well) for an appropriate duration for the assay type (viability, cell death, etc.). Control cells were treated with medium containing $\leq 0.1 \%$ of DMSO.

\subsection{Cell Viability and Cell Death}

The viability of neuron-like SH-SY5Y cells growing in 96-well microplates (with ca. 7000 cells per well) after $24 \mathrm{~h}$ of treatments was evaluated by the Calcein AM assay with minor modification [31]. The Calcein AM solution in PBS used had $0.75 \mu \mathrm{M}$ concentration and the incubation time was set to $50 \mathrm{~min}$. The number of living cells in each well was determined using an Infinite M200 Pro microplate reader (Tecan, Austria), with 495 and $517 \mathrm{~nm}$ excitation and emission wavelengths, respectively.

Cell death of neuron-like cells (SAL model: 10,000 cells per well; Glu-model: 20,000 cells per well) was determined by PI assay as reported by Stone et al. 2003 with small modification [83]. Briefly, the medium of SAL-induced model was aspirated and changed to a $1 \mu \mathrm{g} / \mathrm{mL}$ solution of PI in PBS, but cells subjected to Glu-induction have weaker adherence so a $1 \mathrm{mg} / \mathrm{mL}$ solution of PI in PBS was added to give a final concentration of $1 \mu \mathrm{g} / \mathrm{mL}$. In both cases, cells were incubated for a further 15-25 $\mathrm{min}$ at room temperature then PI fluorescence was measured by an Infinite M200 Pro reader (Tecan, Grödig, Austria) with 535 and 617 excitation and emission wavelengths, respectively. The resulting PI fluorescence obtained with toxins alone was set as $100 \%$ cell death.

\subsection{Measurement of Oxidative Stress by the Dihydroethidium (DHE) assay}

Cells were differentiated and treated as described in the previous section for SALinduction (10,000 cells per well, $24 \mathrm{~h}$ or Glu-induction (20,000 cells per well, $4 \mathrm{~h})$. After the treatments, cells were centrifuged at $500 \times g$ for $330 \mathrm{~s}$, then the culture media were replaced (following aspiration) with $10 \mu \mathrm{M}$ DHE solution in PBS. 96-multiwell plates with cells were incubated in the dark for $30 \mathrm{~min}$ at room temperature, then DHE fluorescence was measured by an Infinite M200 Pro microplate reader (Tecan, Grödig, Austria) with 500 and $580 \mathrm{~nm}$ excitation and emission wavelengths, respectively. The resulting DHE fluorescence obtained with SAL or Glu alone was set as 100\% superoxide radical formation. Illustrative fluorescence microphotographs of DHE-stained cells were obtained after DHE measurement with the microplate reader.

\subsection{Measurement of Caspase-3/7 Activity}

One-step caspase- $3 / 7$ assays were performed according to a previously published procedure [84]. For cultures subjected to SAL-induction and Glu-induction, the reaction mixtures (caspase-3,7 buffer and components with cells in 96-multiwell plates) were incubated for $2 \mathrm{~h}$ and $3 \mathrm{~h}$ at $37^{\circ} \mathrm{C}$, respectively. Caspase-3/7 activity was then measured by an Infinite M200 Pro microplate reader (Tecan, Austria) with 346 and $438 \mathrm{~nm}$ excitation and emission wavelengths, respectively. 


\subsection{Statistical Analysis}

Experiments were performed in triplicates and repeated in three to five $(n=3-5)$ independent days. All data are expressed as mean \pm SEM. Values for all measured variables are expressed as means \pm SEM, which were calculated using Prism 8.4.3 (GraphPad software, La Jolla, CA, USA), which was also used to generate the figures. The statistical analysis was carried by the PAST (ver. 1.97) software package [85]. For differentiation experiment the Student $t$ test was used. The rest of experiments were evaluated by nonparametric Kruskal-Wallis test with Mann-Whitney post hoc test with sequential Bonferroni correction. A value of $p<0.05$ was considered significant.

Supplementary Materials: Original images are available online.

Author Contributions: Contributions of the authors were as follows: Investigation, methodology, validation, data analysis, G.G., C.W.D., and J.G.; writing-original draft preparation G.G., C.W.D., and M.S.; data curation, funding acquisition, supervision, writing-review and editing, C.W.D., M.S., and P.K. All authors have read and agreed to the published version of the manuscript.

Funding: This work was supported financially in part by grants from the Internal Grant Agency of Palacký University in Olomouc, Czech Republic (IGA_PrF_2020_021), the Czech Grant Agency (2015621S) and the European Regional Development Fund-Project ENOCH (No. CZ.02.1.01/0.0/0.0/ 16_019/0000868) and a student grant from Palacký University's Endowment Fund.

Institutional Review Board Statement: Not applicable.

Informed Consent Statement: Not applicable.

Data Availability Statement: Data is contained within the article or supplementary material.

Acknowledgments: Authors thank Dita Jordová, Jana Hrubešová and Lucie Koplíková for excellent technical assistance. Additionally authors thank to Sees-editing Ltd., U.K. for English editing of the manuscript.

Conflicts of Interest: The authors declare no conflict of interest.

Sample Availability: Samples of the compounds are not available from the authors.

\section{References}

1. Dorsey, E.R.; Sherer, T.; Okun, M.S.; Bloem, B.R. The Emerging Evidence of the Parkinson Pandemic. J. Parkinsons Dis. 2018, 8, S3-S8. [CrossRef] [PubMed]

2. Rizek, P.; Kumar, N.; Jog, M.S. An update on the diagnosis and treatment of Parkinson disease. CMAJ Can. Med Assoc. J. 2016, 188, 1157-1165. [CrossRef] [PubMed]

3. Jankovic, J. Progression of Parkinson disease: Are we making progress in charting the course? Arch. Neurol. 2005, 62, 351-352. [CrossRef] [PubMed]

4. Sian, J.; Dexter, D.T.; Lees, A.J.; Daniel, S.; Agid, Y.; Javoy-Agid, F.; Jenner, P.; Marsden, C.D. Alterations in glutathione levels in Parkinson's disease and other neurodegenerative disorders affecting basal ganglia. Ann. Neurol. 1994, 36, 348-355. [CrossRef]

5. Alam, Z.I.; Daniel, S.E.; Lees, A.J.; Marsden, D.C.; Jenner, P.; Halliwell, B. A generalised increase in protein carbonyls in the brain in Parkinson's but not incidental Lewy body disease. J. Neurochem. 1997, 69, 1326-1329. [CrossRef]

6. Alam, Z.I.; Jenner, A.; Daniel, S.E.; Lees, A.J.; Cairns, N.; Marsden, C.D.; Jenner, P.; Halliwell, B. Oxidative DNA damage in the parkinsonian brain: An apparent selective increase in 8-hydroxyguanine levels in substantia nigra. J. Neurochem. 1997, 69, 1196-1203. [CrossRef]

7. Park, J.-S.; Davis, R.L.; Sue, C.M. Mitochondrial Dysfunction in Parkinson's Disease: New Mechanistic Insights and Therapeutic Perspectives. Curr. Neurol. Neurosci. Rep. 2018, 18, 21. [CrossRef]

8. Ambrosi, G.; Cerri, S.; Blandini, F. A further update on the role of excitotoxicity in the pathogenesis of Parkinson's disease. J. Neural Transm. 2014, 121, 849-859. [CrossRef]

9. Dantuma, N.P.; Bott, L.C. The ubiquitin-proteasome system in neurodegenerative diseases: Precipitating factor, yet part of the solution. Front. Mol. Neurosci. 2014, 7, 70. [CrossRef]

10. Cookson, M.R.; Bandmann, O. Parkinson's disease: Insights from pathways. Hum. Mol. Genet. 2010, 19, R21-R27. [CrossRef]

11. Rinne, U.K. Problems associated with long-term levodopa treatment of Parkinson's disease. Acta Neurol. Scand. Suppl. 1983, 95, 19-26. [CrossRef] [PubMed]

12. Corona, J.C. Natural Compounds for the Management of Parkinson's Disease and Attention-Deficit/Hyperactivity Disorder. BioMed Res. Int. 2018, 2018, 4067597. [CrossRef] [PubMed] 
13. Kieber, J.J. Tribute to Folke Skoog: Recent Advances in our Understanding of Cytokinin Biology. J. Plant Growth Regul. 2002, 21, 1-2. [CrossRef] [PubMed]

14. Voller, J.; Maková, B.; Kadlecová, A.; Gonzalez, G.; Strnad, M. Plant Hormone Cytokinins for Modulating Human Aging and Age-Related Diseases. In Hormones in Ageing and Longevity; Rattan, S., Sharma, R., Eds.; Springer International Publishing: Cham, Switzerland, 2017; pp. 311-335.

15. Rattan, S.I.; Sodagam, L. Gerontomodulatory and youth-preserving effects of zeatin on human skin fibroblasts undergoing aging in vitro. Rejuvenation Res 2005, 8, 46-57. [CrossRef] [PubMed]

16. Liu, Y.; Zhang, Z.; Yang, X. Kinetin protects against lipid peroxidation and improves antioxidant status in cultured astrocytes and mouse brain exposed to D-galactose. Afr. J. Biotechnol. 2011, 10, 11721-11727.

17. Hertz, N.T.; Berthet, A.; Sos, M.L.; Thorn, K.S.; Burlingame, A.L.; Nakamura, K.; Shokat, K.M. A neo-substrate that amplifies catalytic activity of parkinson's-disease-related kinase PINK1. Cell 2013, 154, 737-747. [CrossRef]

18. Wei, Y.; Liu, D.; Zheng, Y.; Hao, C.; Li, H.; Ouyang, W. Neuroprotective Effects of Kinetin Against Glutamate-Induced Oxidative Cytotoxicity in HT22 Cells: Involvement of Nrf2 and Heme Oxygenase-1. Neurotox. Res. 2018, 33, 725-737. [CrossRef]

19. Lee, Y.-C.; Yang, Y.-C.; Huang, C.-L.; Kuo, T.-Y.; Lin, J.-H.; Yang, D.-M.; Huang, N.-K. When Cytokinin, a Plant Hormone, Meets the Adenosine A2A Receptor: A Novel Neuroprotectant and Lead for Treating Neurodegenerative Disorders? PLoS ONE 2012, 7, e38865. [CrossRef]

20. Brizzolari, A.; Marinello, C.; Carini, M.; Santaniello, E.; Biondi, P.A. Evaluation of the antioxidant activity and capacity of some natural N6-substituted adenine derivatives (cytokinins) by fluorimetric and spectrophotometric assays. J. Chromatogr. B 2016, 1019, 164-168. [CrossRef]

21. McDaniel, D.H.; Neudecker, B.A.; DiNardo, J.C.; Lewis Ii, J.A.; Maibach, H.I. Idebenone: A new antioxidant-Part I. Relative assessment of oxidative stress protection capacity compared to commonly known antioxidants. J. Cosmet. Dermatol. 2005, 4, 10-17. [CrossRef]

22. Dassano, A.; Mancuso, M.; Giardullo, P.; De Cecco, L.; Ciuffreda, P.; Santaniello, E.; Saran, A.; Dragani, T.A.; Colombo, F. N(6)isopentenyladenosine and analogs activate the NRF2-mediated antioxidant response. Redox Biol. 2014, 2, 580-589. [CrossRef] [PubMed]

23. Forster, J.I.; Köglsberger, S.; Trefois, C.; Boyd, O.; Baumuratov, A.S.; Buck, L.; Balling, R.; Antony, P.M. Characterization of Differentiated SH-SY5Y as Neuronal Screening Model Reveals Increased Oxidative Vulnerability. J. Biomol. Screen. 2016, 21, 496-509. [CrossRef] [PubMed]

24. Dwane, S.; Durack, E.; Kiely, P.A. Optimising parameters for the differentiation of SH-SY5Y cells to study cell adhesion and cell migration. BMC Res. Notes 2013, 6, 366. [CrossRef] [PubMed]

25. Xicoy, H.; Wieringa, B.; Martens, G.J.M. The SH-SY5Y cell line in Parkinson's disease research: A systematic review. Mol. Neurodegener. 2017, 12, 10. [CrossRef]

26. Kurnik-Łucka, M.; Panula, P.; Bugajski, A.; Gil, K. Salsolinol: An Unintelligible and Double-Faced Molecule-Lessons Learned from In Vivo and In Vitro Experiments. Neurotox. Res. 2018, 33, 485-514. [CrossRef]

27. Li, C.; Chai, S.; Ju, Y.; Hou, L.; Zhao, H.; Ma, W.; Li, T.; Sheng, J.; Shi, W. Pu-erh Tea Protects the Nervous System by Inhibiting the Expression of Metabotropic Glutamate Receptor 5. Mol. Neurobiol. 2017, 54, 5286-5299. [CrossRef]

28. Ou, B.; Hampsch-Woodill, M.; Prior, R.L. Development and validation of an improved oxygen radical absorbance capacity assay using fluorescein as the fluorescent probe. J. Agric. Food Chem. 2001, 49, 4619-4626. [CrossRef]

29. McBean, G.J.; López, M.G.; Wallner, F.K. Redox-based therapeutics in neurodegenerative disease. Br. J. Pharmacol. 2017, 174, 1750-1770. [CrossRef]

30. Cheung, Y.-T.; Lau, W.K.-W.; Yu, M.-S.; Lai, C.S.-W.; Yeung, S.-C.; So, K.-F.; Chang, R.C.-C. Effects of all-trans-retinoic acid on human SH-SY5Y neuroblastoma as in vitro model in neurotoxicity research. Neurotoxicology 2009, 30, 127-135. [CrossRef]

31. Rárová, L.; Steigerová, J.; Kvasnica, M.; Bartůněk, P.; Kř́žzvová, K.; Chodounská, H.; Kolář, Z.; Sedlák, D.; Oklestkova, J.; Strnad, M. Structure activity relationship studies on cytotoxicity and the effects on steroid receptors of AB-functionalized cholestanes. J. Steroid Biochem. Mol. Biol. 2016, 159, 154-169. [CrossRef]

32. Voller, J.; Zatloukal, M.; Lenobel, R.; Dolezal, K.; Béres, T.; Krystof, V.; Spíchal, L.; Niemann, P.; Dzubák, P.; Hajdúch, M.; et al. Anticancer activity of natural cytokinins: A structure-activity relationship study. Phytochemistry 2010, 71, 1350-1359. [CrossRef] [PubMed]

33. Texel, S.J.; Zhang, J.; Camandola, S.; Unger, E.L.; Taub, D.D.; Koehler, R.C.; Harris, Z.L.; Mattson, M.P. Ceruloplasmin Deficiency Reduces Levels of Iron and BDNF in the Cortex and Striatum of Young Mice and Increases Their Vulnerability to Stroke. PLoS ONE 2011, 6, e25077. [CrossRef] [PubMed]

34. Guan, H.; Yang, H.; Yang, M.; Yanagisawa, D.; Bellier, J.-P.; Mori, M.; Takahata, S.; Nonaka, T.; Zhao, S.; Tooyama, I. Mitochondrial ferritin protects SH-SY5Y cells against H2O2-induced oxidative stress and modulates $\alpha$-synuclein expression. Exp. Neurol. 2017, 291, 51-61. [CrossRef] [PubMed]

35. Hirayama, N.; Aki, T.; Funakoshi, T.; Noritake, K.; Unuma, K.; Uemura, K. Necrosis in human neuronal cells exposed to paraquat. J. Toxicol. Sci. 2018, 43, 193-202. [CrossRef]

36. Ito, K.; Eguchi, Y.; Imagawa, Y.; Akai, S.; Mochizuki, H.; Tsujimoto, Y. MPP+ induces necrostatin-1- and ferrostatin-1-sensitive necrotic death of neuronal SH-SY5Y cells. Cell Death Discov. 2017, 3, 17013. [CrossRef]

37. Wanpen, S.; Govitrapong, P.; Shavali, S.; Sangchot, P.; Ebadi, M. Salsolinol, a dopamine-derived tetrahydroisoquinoline, induces cell death by causing oxidative stress in dopaminergic SH-SY5Y cells, and the said effect is attenuated by metallothionein. Brain Res. 2004, 1005, 67-76. [CrossRef] 
38. Dengler, W.A.; Schulte, J.; Berger, D.P.; Mertelsmann, R.; Fiebig, H.H. Development of a propidium iodide fluorescence assay for proliferation and cytotoxicity assays. Anti-Cancer Drugs 1995, 6, 522-532. [CrossRef]

39. Othman, E.M.; Naseem, M.; Awad, E.; Dandekar, T.; Stopper, H. The Plant Hormone Cytokinin Confers Protection against Oxidative Stress in Mammalian Cells. PLoS ONE 2016, 11, e0168386. [CrossRef]

40. Yap, Y.; Omasanggar, R.; Koh, Y.L.; Yew, M.Y.; Lai, H.T.; Ling, A.P.K.; Chye, S.M.; Ng, K.Y.; Koh, R.Y. Neurotoxic effect of salsolinol through oxidative stress induction and Nrf2-Keap1 signalling regulation. J. Chem. Pharm. Res. 2016, 8, 30-38.

41. Bindokas, V.P.; Jordan, J.; Lee, C.C.; Miller, R.J. Superoxide production in rat hippocampal neurons: Selective imaging with hydroethidine. J. Neurosci. 1996, 16, 1324-1336. [CrossRef]

42. Carter, W.O.; Narayanan, P.K.; Robinson, J.P. Intracellular hydrogen peroxide and superoxide anion detection in endothelial cells. J. Leukoc. Biol. 1994, 55, 253-258. [PubMed]

43. Wanpen, S.; Kooncumchoo, P.; Shavali, S.; Govitrapong, P.; Ebadi, M. Salsolinol, an endogenous neurotoxin, activates JNK and NF-kappaB signaling pathways in human neuroblastoma cells. Neurochem. Res. 2007, 32, 443-450. [CrossRef] [PubMed]

44. Jabłońska-Trypuć, A.; Matejczyk, M.; Czerpak, R. N6-benzyladenine and kinetin influence antioxidative stress parameters in human skin fibroblasts. Mol. Cell. Biochem. 2016, 413, 97-107. [CrossRef] [PubMed]

45. Goldstein, S.; Czapski, G. SOD-like activity studies of cytokinin-copper(II) complexes. Free Radic. Res. Commun. 1991, 12, 173-177. [CrossRef] [PubMed]

46. Štarha, P.; Trávníček, Z.; Herchel, R.; Popa, I.; Suchý, P.; Vančo, J. Dinuclear copper(II) complexes containing 6-(benzylamino)purines as bridging ligands: Synthesis, characterization, and in vitro and in vivo antioxidant activities. J. Inorg. Biochem. 2009, 103, 432-440. [CrossRef] [PubMed]

47. De Lazzari, F.; Bubacco, L.; Whitworth, A.J.; Bisaglia, M. Superoxide Radical Dismutation as New Therapeutic Strategy in Parkinson's Disease. Aging Dis. 2018, 9, 716-728. [CrossRef]

48. Lalkovičová, M.; Danielisová, V. Neuroprotection and antioxidants. Neural Regen. Res. 2016, 11, 865-874. [CrossRef]

49. Surendran, S.; Raja Sankar, S. Parkinson's disease: Oxidative stress and therapeutic approaches. Neurol. Sci. 2010, 31, 531-540. [CrossRef]

50. Lee, K.H.; Cha, M.; Lee, B.H. Neuroprotective Effect of Antioxidants in the Brain. Int. J. Mol. Sci. 2020, 21, 7152. [CrossRef]

51. Bollimuntha, S.; Ebadi, M.; Singh, B.B. TRPC1 protects human SH-SY5Y cells against salsolinol-induced cytotoxicity by inhibiting apoptosis. Brain Res. 2006, 1099, 141-149. [CrossRef]

52. Walsh, J.G.; Cullen, S.P.; Sheridan, C.; Lüthi, A.U.; Gerner, C.; Martin, S.J. Executioner caspase-3 and caspase-7 are functionally distinct proteases. Proc. Natl. Acad. Sci. USA 2008, 105, 12815. [CrossRef] [PubMed]

53. Jantas, D.; Piotrowski, M.; Lason, W. An Involvement of PI3-K/Akt Activation and Inhibition of AIF Translocation in Neuroprotective Effects of Undecylenic Acid (UDA) Against Pro-Apoptotic Factors-Induced Cell Death in Human Neuroblastoma SH-SY5Y Cells. J. Cell. Biochem. 2015, 116, 2882-2895. [CrossRef] [PubMed]

54. Brown, D.; Tamas, A.; Reglödi, D.; Tizabi, Y. PACAP Protects Against Salsolinol-Induced Toxicity in Dopaminergic SH-SY5Y Cells: Implication for Parkinson's Disease. J. Mol. Neurosci. 2013, 50, 600-607. [CrossRef] [PubMed]

55. Cheng, B.; Anand, P.; Kuang, A.; Akhtar, F.; Scofield, V.L. N-Acetylcysteine in Combination with IGF-1 Enhances Neuroprotection against Proteasome Dysfunction-Induced Neurotoxicity in SH-SY5Y Cells. Parkinsons Dis. 2016, 2016, 6564212. [CrossRef]

56. Li, J.; Meng, Z.; Zhang, G.; Xing, Y.; Feng, L.; Fan, S.; Fan, F.; Buren, B.; Liu, Q. N-acetylcysteine relieves oxidative stress and protects hippocampus of rat from radiation-induced apoptosis by inhibiting caspase-3. Biomed. Pharmacother. 2015, 70, 1-6. [CrossRef]

57. Rakshit, J.; Mallick, A.; Roy, S.; Sarbajna, A.; Dutta, M.; Bandyopadhyay, J. Iron-Induced Apoptotic Cell Death and Autophagy Dysfunction in Human Neuroblastoma Cell Line SH-SY5Y. Biol. Trace Elem. Res. 2019, 193, 138-151. [CrossRef]

58. Rakshit, J.; Priyam, A.; Gowrishetty, K.K.; Mishra, S.; Bandyopadhyay, J. Iron chelator Deferoxamine protects human neuroblastoma cell line SH-SY5Y from 6-Hydroxydopamine-induced apoptosis and autophagy dysfunction. J. Trace Elem. Med. Biol. 2020, 57, 126406. [CrossRef]

59. Ma, X.W.; Guo, R.Y. Dose-dependent effect of Curcuma longa for the treatment of Parkinson's disease. Exp. Ther. Med. 2017, 13, 1799-1805. [CrossRef]

60. Naoi, M.; Maruyama, W.; Takahashi, T.; Akao, Y.; Nakagawa, Y. Involvement of endogenous N-methyl(R)salsolinol in Parkinson's disease: Induction of apoptosis and protection by (-)deprenyl. In Advances in Research on Neurodegeneration; Mizuno, Y., Calne, D.B., Horowski, R., Poewe, W., Riederer, P., Youdim, M.B.H., Eds.; Springer: Vienna, Austria, 2000; pp. 111-121.

61. Kulikov, A.V.; Rzhaninova, A.A.; Goldshtein, D.V.; Boldyrev, A.A. Expression of NMDA receptors in multipotent stromal cells of human adipose tissue under conditions of retinoic acid-induced differentiation. Bull. Exp. Biol. Med. 2007, 144, 626-629. [CrossRef]

62. Kritis, A.A.; Stamoula, E.G.; Paniskaki, K.A.; Vavilis, T.D. Researching glutamate-Induced cytotoxicity in different cell lines: A comparative/collective analysis/study. Front. Cell. Neurosci. 2015, 9, 91. [CrossRef]

63. Sun, X.; Shi, X.; Lu, L.; Jiang, Y.; Liu, B. Stimulus-dependent neuronal cell responses in SH-SY5Y neuroblastoma cells. Mol. Med. Rep. 2016, 13, 2215-2220. [CrossRef] [PubMed]

64. Cunha, M.P.; Lieberknecht, V.; Ramos-Hryb, A.B.; Olescowicz, G.; Ludka, F.K.; Tasca, C.I.; Gabilan, N.H.; Rodrigues, A.L.S. Creatine affords protection against glutamate-induced nitrosative and oxidative stress. Neurochem. Int. 2016, 95, 4-14. [CrossRef] [PubMed]

65. Mou, Y.; Wang, J.; Wu, J.; He, D.; Zhang, C.; Duan, C.; Li, B. Ferroptosis, a new form of cell death: Opportunities and challenges in cancer. J. Hematol. Oncol. 2019, 12, 34. [CrossRef] [PubMed]

66. Zille, M.; Kumar, A.; Kundu, N.; Bourassa, M.W.; Wong, V.S.C.; Willis, D.; Karuppagounder, S.S.; Ratan, R.R. Ferroptosis in Neurons and Cancer Cells Is Similar But Differentially Regulated by Histone Deacetylase Inhibitors. eNeuro 2019, 6. [CrossRef] 
67. Jantas, D.; Chwastek, J.; Grygier, B.; Lason, W. Neuroprotective Effects of Necrostatin-1 Against Oxidative Stress-Induced Cell Damage: An Involvement of Cathepsin D Inhibition. Neurotox. Res. 2020, 37, 525-542. [CrossRef]

68. Sun, Z.W.; Zhang, L.; Zhu, S.J.; Chen, W.C.; Mei, B. Excitotoxicity effects of glutamate on human neuroblastoma SH-SY5Y cells via oxidative damage. Neurosci. Bull. 2010, 26, 8-16. [CrossRef]

69. Chu, J.; Liu, C.-X.; Song, R.; Li, Q.-L. Ferrostatin-1 protects HT-22 cells from oxidative toxicity. Neural Regen. Res. 2020, 15, $528-536$.

70. Xu, X.; Chua, C.C.; Kong, J.; Kostrzewa, R.M.; Kumaraguru, U.; Hamdy, R.C.; Chua, B.H. Necrostatin-1 protects against glutamateinduced glutathione depletion and caspase-independent cell death in HT-22 cells. J. Neurochem. 2007, 103, 2004-2014. [CrossRef]

71. Shirlee, T.; David, S.; Pamela, M. Oxytosis: A Novel Form of Programmed Cell Death. Curr. Top. Med. Chem. 2001, 1, 497-506. [CrossRef]

72. Nikolova, S.; Lee, Y.S.; Lee, Y.-S.; Kim, J.-A. Rac1-NADPH oxidase-regulated generation of reactive oxygen species mediates glutamate-induced apoptosis in SH-SY5Y human neuroblastoma cells. Free Radic. Res. 2005, 39, 1295-1304. [CrossRef]

73. Jelinek, A.; Heyder, L.; Daude, M.; Plessner, M.; Krippner, S.; Grosse, R.; Diederich, W.; Culmsee, C. Mitochondrial rescue prevents glutathione peroxidase-dependent ferroptosis. Free Radic. Biol. Med. 2018, 117, 45-57. [CrossRef]

74. Olsen, A.; Siboska, G.E.; Clark, B.F.C.; Rattan, S.I.S. N6-Furfuryladenine, Kinetin, Protects against Fenton Reaction-Mediated Oxidative Damage to DNA. Biochem. Biophys. Res. Commun. 1999, 265, 499-502. [CrossRef] [PubMed]

75. Sharma, S.P.; Kaur, J.; Rattan, S.I.S. Increased longevity of kinetin-fed Zaprionus fruitflies is accompanied by their reduced fecundity and enhanced catalase activity. IUBMB Life 1997, 41, 869-875. [CrossRef] [PubMed]

76. Choi, S.J.; Jeong, C.H.; Choi, S.G.; Chun, J.Y.; Kim, Y.J.; Lee, J.; Shin, D.H.; Heo, H.J. Zeatin prevents amyloid beta-induced neurotoxicity and scopolamine-induced cognitive deficits. J. Med. Food 2009, 12, 271-277. [CrossRef] [PubMed]

77. Yang, S.-J.; Han, A.R.; Kim, E.-A.; Yang, J.W.; Ahn, J.-Y.; Na, J.-M.; Cho, S.-W. KHG21834 attenuates glutamate-induced mitochondrial damage, apoptosis, and NLRP3 inflammasome activation in SH-SY5Y human neuroblastoma cells. Eur. J. Pharmacol. 2019, 856, 172412. [CrossRef] [PubMed]

78. Yuksel, T.N.; Yayla, M.; Halici, Z.; Cadirci, E.; Polat, B.; Kose, D. Protective effect of 5-HT7 receptor activation against glutamateinduced neurotoxicity in human neuroblastoma SH-SY5Y cells via antioxidative and antiapoptotic pathways. Neurotoxicol. Teratol. 2019, 72, 22-28. [CrossRef]

79. Lee, H.J.; Spandidos, D.A.; Tsatsakis, A.; Margina, D.; Izotov, B.N.; Yang, S.H. Neuroprotective effects of Scrophularia buergeriana extract against glutamate-induced toxicity in SH-SY5Y cells. Int. J. Mol. Med. 2019, 43, 2144-2152. [CrossRef]

80. Hu, Y.; Li, J.; Liu, P.; Chen, X.; Guo, D.-H.; Li, Q.-S.; Rahman, K. Protection of SH-SY5Y Neuronal Cells from Glutamate-Induced Apoptosis by 3,6'-Disinapoyl Sucrose, a Bioactive Compound Isolated from Radix Polygala. J. Biomed. Biotechnol. 2012, 2012, 728342. [CrossRef]

81. Geng, N.; Shi, B.J.; Li, S.L.; Zhong, Z.Y.; Li, Y.C.; Xua, W.L.; Zhou, H.; Cai, J.H. Knockdown of ferroportin accelerates erastininduced ferroptosis in neuroblastoma cells. Eur. Rev. Med. Pharmacol. Sci. 2018, 22, 3826-3836.

82. Krishnamurthy, P.; Mays, J.; Bijur, G.; Johnson, G. Transient oxidative stress in SH-SY5Y human neuroblastoma cells results in caspase dependent and independent cell death and tau proteolysis. J. Neurosci. Res. 2000, 61, 515-523. [CrossRef]

83. Stone, W.L.; Qui, M.; Smith, M. Lipopolysaccharide enhances the cytotoxicity of 2-chloroethyl ethyl sulfide. BMC Cell Biol. 2003, 4, 1-7. [CrossRef] [PubMed]

84. Carrasco, R.A.; Stamm, N.B.; Patel, B.K.R. One-step cellular caspase-3/7 assay. BioTechniques 2003, 34, 1064-1067. [CrossRef] [PubMed]

85. Hammer, O.; Harper, D.; Ryan, P. PAST: Paleontological Statistics Software Package for Education and Data Analysis. Palaeontol. Electron. 2001, 4, 1-9. 